\title{
CSAK NYOMÁSNAK ELLENÁLLÓ, ALAKVÁLTOZÁSRA FELLÁGYULÓ ANYAGÚ FALAZAT - VÁLYOGFALAZAT - TEHERBÍRÁSA
}

\author{
O. CSICSELY ÁGNES* - SAJTOS ISTVÁN**
}

\begin{abstract}
*okl. építészmérnök, PhD, egyetemi adjunktus. BME Szilárdságtani és Tartószerkezeti Tanszék 1111 Budapest, Múegyetem rkp. 3. K II. 61. Fax: +36 1463 1773. E-mail: csicsely@szt.bme.hu

**okl. építőmérnök, PhD, egyetemi docens. BME Szilárdságtani és Tartószerkezeti Tanszék 1111 Budapest, Mủegyetem rkp. 3. K II. 61. Fax: +36 1463 1773. E-mail: sajtos@szt.bme.hu
\end{abstract}

\begin{abstract}
Vályogfalazat teherbírását határoztuk meg külpontos nyomásra. A teherbírást, a kísérleteknek megfelelő, csak nyomásnak ellenálló, alakváltozásra fellágyuló anyagmodellel számítottuk. A javasolt anyagmodell paramétereinek változtatásával a mérnöki gyakorlatban használt anyagmodellek mindegyike előállítható. A falazat teherbírását nem lehet elöírt tönkremeneteli állapotokat kiválasztva meghatározni. A tönkremenetelt jelentő igénybevételt a keresztmetszet nyomaték-görbület függvényének maximuma szolgáltatja. Megállapítottuk, hogy a tönkremenetelt jelentő állapotot nem feltétlenül jelzi előre repedés. Ugyanakkor a falazat viselkedése is változik, a duktilistól a ridegig, az igénybevételek változásával. Azt is megállapítottuk, hogy a falazat magsávja, ami a repedésmentes állapothoz tartozó külpontos erök tartománya, függ a javasolt anyagtörvény paramétereitől és a müködő nyomóerő nagyságától is. Javaslatot tettünk egy egyszerübb, de elfogadható pontosságú, a javasolt anyagtörvényt helyettesítő, anyagtörvényre is.
\end{abstract}

Kulcsszavak: vályog, falazat, fellágyuló anyag, teherbírási vonal

\section{BEVEZETÉS}

A vályog- és földépítés a legősibb építéstechnológiák egyike. A több ezer éves múltra visszatekintő vályogépítést mind a mai napig használják épületek készítésére. A hazai épületállománynak is több mint $25 \%$-a föld- és vályogfalú [16]. A rossz helyre épített, rosszul karbantartott épületek miatt elterjedt az a nézet, miszerint ez az építési mód elavult és nem felel meg a XXI. századi követelményeknek.

Mára azonban egyértelmüen kiderültek a vályogépítés előnyei is. Az ökologikus vagy környezettudatos építési mód a vályogban rejlő lehetőségeket kívánja kihasználni a korszerủ építészeti igényeket figyelembe véve. A vályognak mint természetes építőanyagnak építésbiológiailag kedvező hatása van az emberre, és az építése, fenntartása kevésbé terheli a környezetet.

A vályog a természetben előforduló szervetlen alkotórészek (agyag) és az esetlegesen hozzáadott tulajdonságjavítók (homokos kavics, mész, cement, növényi rostok /szalma, nád/ stb.) vizes keveréke. A vályog falazóelemeket nagy víztartalmú keverékből szárítással (vetett vályog), míg alacsony víztartalmú keverék esetén préseléssel állítják elő. 
A vályogépítés fejlesztésének két iránya van: a) amikor a falazóelemek szilárdságának a növelése a cél, pl. cementes stabilizálással; $b$ ) amikor a falazóelemek hőszigetelö képességének a növelése, pl. a vályog falazóelemek különböző anyagokkal (szalma, nád stb.) történő könnyítése révén.

Természetes igény, hogy a vályogfalak méretezése is tudományosan megalapozott és egységesen szabályozott legyen. Bár sokszor, sok helyen kezdeményezték a vályogfalak méretezésének korszerü alapokra helyezését, ennek ellenére máig nincs egységes szabályozás pl. az Európai Unióban sem.

Az utóbbi 15-20 évben azonban intenzív kutatás kezdődött a vályog építészeti és tartószerkezeti alkalmazási lehetőségeinek megismerésére és méretezési módszereinek kidolgozására.

Égetett agyag falazóelemekből épült falazat esetén is nyomásra fellágyuló viselkedés tapasztalható a kísérletekben, bár különböző lehet az eltérő anyagú falazóelemekből épült falazatok alakváltozó képessége (1.a, b ábrák). A valódi viselkedést azonban a számításokban általában lineárisan rugalmas-tökéletesen képlékeny anyagmodellel közelítik. Ismeretes azonban [7], hogy a lineárisan rugalmas-tökéletesen képlékeny anyagmodell alakváltozó képességének korlátozása, azaz véges alakváltozó képesség is, csökkenti a falazat teherbírását.

Dolgozatunkban a vályogfalak teherbírásának olyan számítási módját mutatjuk be, ami a falazat valódi - alakváltozásra fellágyuló - viselkedését veszi figyelembe (1.c ábra) $[5,6]$.
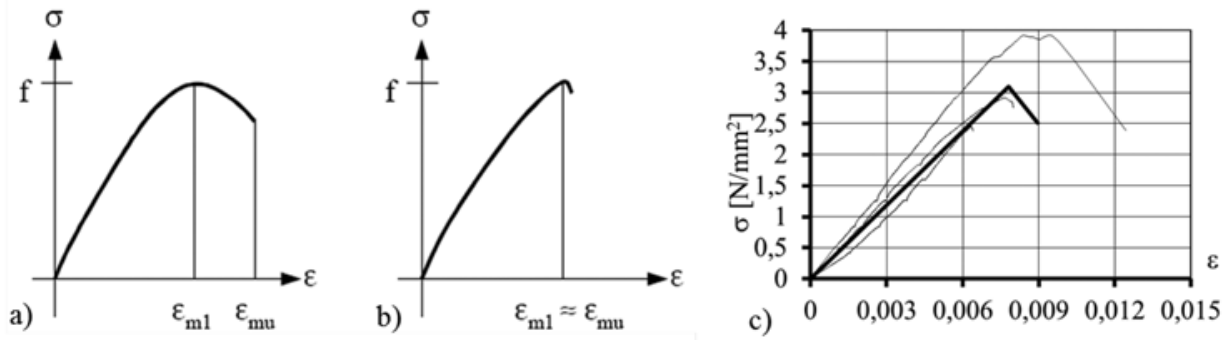

1. ábra. A falazat viselkedése nyomásra: a) égetett agyag falazat, ,,duktilis” viselkedés; $b$ ) égetett agyag falazat, rideg viselkedés [9]; c) vályogfalazat, alakváltozásra fellágyuló viselkedés (- kísérleti eredmények, - a kísérleti eredményekre illesztett függvény) [5, 6]

Megvizsgáljuk, hogy a nyomásra fellágyuló, valós viselkedés hogyan befolyásolja a falazat teherbírását, tönkremeneteli módját és az alakváltozó képességét. Ezen kívül azt is, hogy a teherbírás kimerülését milyen megfigyelhető vagy nem látható jelenségek elözik meg, illetve követik.

Vizsgálataink állandó vastagságú falkeresztmetszet teherbírásának, azaz a szilárdsági tönkremenetelének meghatározására vonatkoznak. A falkeresztmetszet teherbírását a normálerő, hajlítónyomaték együttesére (külpontos nyomásra) teherbírási vonal segítségével adjuk meg. 


\subsection{ALAPFOGALMAK}

A falazott szerkezet inhomogén (falazóelemböl, habarccsal összeépített) anyag, amit térbeli teherviselést lehetővé tevő geometriai rendszerben, kötésben falaznak. A falazott szerkezet elég nagy darabja az ún. reprezentatív térfogatú elem. Ez a mechanika jellemzők szempontjából egységes, a falazóelem, habarcs és kötési mód együttesére jellemző viselkedést mutat. Ez a tény lehetővé teszi azt, hogy az ilyen, makroszkopikusan inhomogén anyagokat is a homogén anyagokra kidolgozott modellek segítségével vizsgáljunk.

A falazott szerkezetek modellezéséhez szükséges anyagjellemzőknek és vizsgálatoknak három egymásra épülő szintje különböztethető meg (2. ábra) [14]. Az első szint a falazott szerkezethez használt anyagok szintje (2.c ábra). Ez a falazóelemeket, a habarcsot és minden más, a falazott szerkezet készítéséhez használt anyagot (pl. falkapcsok, vasalás, feszítő betétek) jelenti.

A második a falazat (falelem) szintje (2.b ábra). A falazat a falazott szerkezetet alkotó anyagokból összeépített faldarab, amelynek mechanikai viselkedését az alkotóelemek és a falazáshoz használt kötési mód határozza meg, de mechanikai jellemzők szempontjából homogénnek tekinthető, ezért az adott igénybevételi állapothoz tartozó egyetlen mechanikai jellemzővel (pl. szilárdsággal) jellemezhető a viselkedése. A falazat tönkremenetelének mindig szilárdsági oka van. Megjegyezzük, hogy a falazat mechanikai jellemzőit még manapság is laboratóriumi kísérletekkel határozzák meg, bár mód van annak elméleti meghatározására is $[17,1]$.

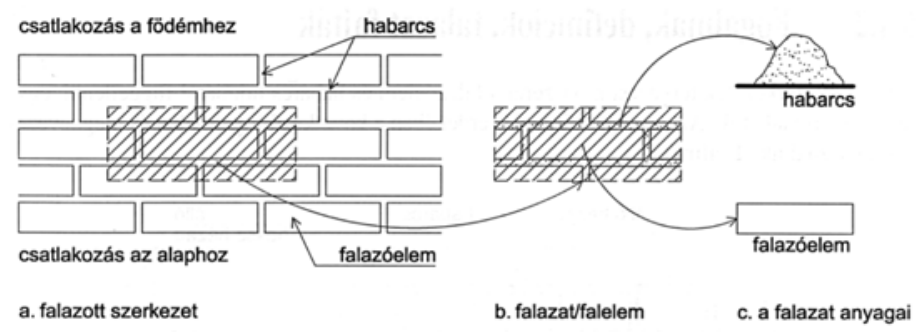

2. ábra. A falazott szerkezet modellezési szintjei: a) falazott szerkezet, b) falazat/falelem, c) a falazat anyagai

A harmadik szint a falazott szerkezet szintje (2.a ábra). A falazott szerkezet (fal, pillér) más szerkezeti elemekkel (pl. födémmel) összeépített falazott szerkezetrész. A falazott szerkezet tönkremenetelének oka lehet stabilitásvesztés (pl. kihajlás) vagy az anyag (falazat) tönkremenetele (szilárdsági ok).

A falazott szerkezet modellezése a falazott szerkezet vagy a falazat szintjén történik. A számításban használt mechanikai jellemzőket mindig az alacsonyabb modellszint határozza meg: falazott szerkezetnél a falazat; falazatnál a falazat készítéséhez használt anyagok. 
A vályogfalazat fekvőhézagra merőleges nyomáshoz tartozó mechanikai jellemzőit kísérletekkel állapítottuk meg [5, 6] (1.c ábra). A kísérleteket az MSZ EN 1052-1 szabvány szerint [12] hajtottuk végre, amelyik egységesen határozza meg a falazott falak reprezentatív térfogatú elemének méretét. A vályogfalazat teherbírását külpontos nyomásra, az általában szokásos módon, de a tényleges viselkedésnek megfelelö, alakváltozásra fellágyuló anyagmodell segítségével határozzuk meg.

\section{A VÁLYOGFALAZAT ALAKVÁLTOZÁSRA FELLÁGYULÓ ANYAGMODELLJE}

A vályogfalazat fekvőhézagra merőleges húzás esetében gyakorlatilag ellenállás nélkül választható szét, ugyanis a falazáshoz használt vályoghabarcs és a falazóelemek közötti tapadás csekély. A modell, a méretezés szempontjából a vályogfalazat húzószilárdság nélküli anyagnak tekinthető. Húzófeszültségek esetében a falazat, a fekvőhézagok mentén, azonnal bereped. Központos és külpontos nyomás esetében lehetséges csak egyensúly.

Fekvőhézagra meröleges, központos nyomás esetében elöször a feszültségek növelésével a keletkező alakváltozások is arányosan nőnek. A maximális feszültség elérése után azonban növekvő alakváltozások csak csökkenő feszültségek mellett tudnak egyensúlyt biztosítani (1.c ábra). A falazatban (a falazóelemben vagy a habarcsban, vagy mindkettőben) a nyomás hatására a nyomás irányával párhuzamos mikro-repedésrendszer alakul ki. Ennek következménye a feszültség alakváltozás ábra eső ága. Ezek a repedések szabad szemmel a falazat felületén még nem láthatóak. Az eső ág végét jelző törési összenyomódás elérésekor alakulnak ki azok a nyomás irányával párhuzamos makrorepedések, amelyek az anyag szétesését, az anyag szilárdsági tönkremenetelét jelentik.

A vályogfalazat viselkedésének modellezésére, a kísérleti eredményeket figyelembe véve csak nyomásnak ellenálló, lineárisan rugalmas-lineárisan fellágyuló anyagtörvény használatát javasoljuk (3. ábra).

A 3. ábrán jelölje a törési összenyomódást $\varepsilon_{u}$, a hozzá tartozó feszültséget $\sigma_{u}$, a maximális feszültséget (a károsodás, mikrorepedések kialakulásának kezdetét) $\sigma_{o}$, a hozzá tartozó alakváltozást $\varepsilon_{o}$. Az anyagmodell rugalmas ágának rugalmassági

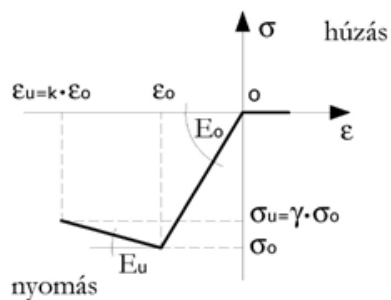

3. ábra. Csak nyomásnak ellenálló, lineárisan rugalmas - lineárisan fellágyuló anyagtörvény feszültség - alakváltozás ábrája 
modulusát $E_{o}$-lal, az alakváltozásra fellágyuló ág meredekségét $E_{u}$-val jelöljük. (A pozitív előjelü feszültség és alakváltozás jelenti a nyomófeszültséget és a hatására bekövetkező fajlagos összenyomódást.)

A javasolt anyagtörvény egyenlete egytengelyü húzás-nyomás esetén:

$$
\begin{array}{ccc}
\sigma=E_{o} \cdot \varepsilon, & \text { ha } & \varepsilon \leq \varepsilon_{o} \\
\sigma=\sigma_{o}-E_{u} \cdot\left(\varepsilon-\varepsilon_{o}\right), & \text { ha } & \varepsilon_{o}<\varepsilon \leq \varepsilon_{u} .
\end{array}
$$

Vezessük be a következő paramétereket:

$$
\begin{array}{cc}
\gamma=\frac{\sigma_{u}}{\sigma_{o}} ; & 0 \leq \gamma \leq 1,0 \\
k=\frac{\varepsilon_{u}}{\varepsilon_{o}} ; & k \geq 1,0 .
\end{array}
$$

Az előbbi két paraméter segítségével összefüggés teremthető az anyagmodell rugalmassági modulusa és az alakváltozásra lágyuló ág meredeksége között.

$$
\left|E_{u}\right|=c \cdot\left|E_{o}\right|, \quad \text { ahol } \quad c=\frac{1-\gamma}{k-1} .
$$

A jelölésekben az $o$ alsó index mindig a rugalmas ág jellemzőit jelzi, az $u$-val jelölt alsó index pedig az alakváltozásra lágyuló ág jellemzőit mutatja.

Az (1) egyenletű anyagtörvény segítségével, a $k$ és $\gamma$ paraméterek alkalmas megválasztásával, a mérnöki gyakorlatban használt anyagmodellek mindegyikét meg lehet adni [10], 1. táblázat.

1. táblázat. Anyagtörvények a $k, \gamma, c$ és $\varepsilon_{u}$ paraméterek függvényében

\begin{tabular}{|c|c|c|c|c|l|}
\hline$\gamma$ & $k$ & $\varepsilon_{u}$ & $\varepsilon_{o}$ & $c$ & \multicolumn{1}{|c|}{ Anyagmodellek } \\
\hline 0 & 1,0 & tetszőleges & $>0$ & $\infty$ & lineárisan rugalmas-rideg \\
\hline 1,0 & $>1,0$ & tetszőleges & $>0$ & 0 & $\begin{array}{l}\text { korlátozott alakváltozású lineárisan rugalmas- } \\
\text { tökéletesen képlékeny }\end{array}$ \\
\hline 1,0 & $\infty$ & $\infty$ & $>0$ & 0 & $\begin{array}{l}\text { alakváltozási korlát nélküli lineárisan } \\
\text { rugalmas-tökéletesen képlékeny }\end{array}$ \\
\hline 1,0 & $>1,0$ & tetszőleges & 0 & 0 & korlátozott alakváltozású merev-képlékeny \\
\hline 1,0 & $\infty$ & $\infty$ & 0 & 0 & alakváltozási korlát nélküli merev-képlékeny \\
\hline$<1,0$ & $>1,0$ & tetszőleges & $>0$ & $0<c<\infty$ & $\begin{array}{l}\text { korlátozott alakváltozású, lineárisan } \\
\text { rugalmas-fellágyuló }\end{array}$ \\
\hline
\end{tabular}


A lineárisan rugalmas anyagmodell (4.a ábra) esetén az alakváltozás és a feszültség között lineáris kapcsolat áll fenn, a terhelés növelésével arányosan nő az alakváltozás nagysága. Tehermentesítés után az alakváltozás megszünik. Nincs feszültség és/vagy alakváltozás korlát, az anyag nem tud tönkremenni.

A lineárisan rugalmas-rideg anyagmodell (4.b ábra) olyan, mint a lineárisan rugalmas anyagmodell azzal a különbséggel, hogy $\sigma=\sigma_{o}$ elérésekor az anyag tönkremenetele hirtelen következik be.

A lineárisan rugalmas-tökéletesen képlékeny anyagmodell szerint az anyag (4.c ábra) a maximális feszültség $\left(\sigma_{o}\right)$ eléréséig rugalmasan viselkedik. A maximális feszültség elérése után az anyag képlékeny állapotba kerül, és alakváltozása állandó nagyságú feszültség mellett korlátlanul növekedhet. Tehermentesítéskor az alakváltozás a feszültséggel arányosan változik, tehát az anyag ismét rugalmasan viselkedik. Ezért a tehermentesítés során a terhelés közben létrejött alakváltozásoknak csak a rugalmas része szünik meg, a képlékeny alakváltozás a tehermentesítés után megmarad.

A merev-tökéletesen képlékeny anyagmodell szerint az anyag (4.d ábra) a maximális feszültség eléréséig nem szenved alakváltozást, a maximális feszültség müködése közben viszont tetszőleges nagyságú alakváltozás keletkezhet. Tehermentesítéskor sem változik az alakváltozás, ezért a terhelés során létrejött teljes alakváltozás a tehermentesítés után is megmarad.

A képlékeny anyagmodelleknél az $\varepsilon_{u}$ törési összenyomódás lehet véges vagy végtelen érték is. Az utóbbit általában a számítások egyszerüsítése miatt feltételezik.

A fellágyuló anyagmodell, 3. ábra, feltételezi, hogy a fellágyuló ághoz tartozó alakváltozások egy kis tartományban koncentrálódnak, lokalizálódnak [3]. Ebben a tartományban bekövetkező energiadisszipáció eredményezi az anyag tönkremenete-

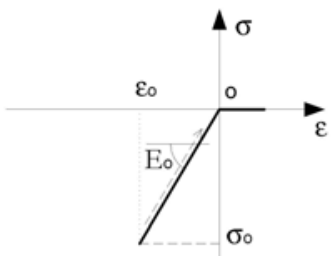

a) lineárisan rugalmas anyagmodell

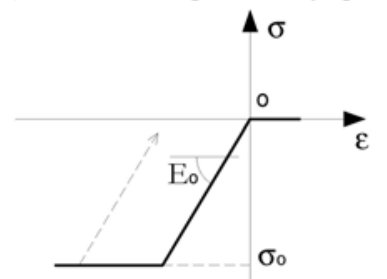

c) lineárisan rugalmas-képlékeny anyagmodell

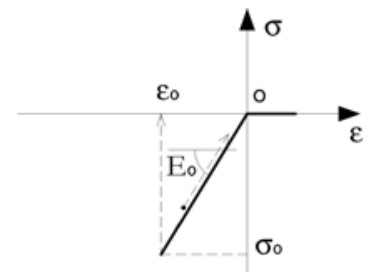

b) lineárisan rugalmas-rideg anyagmodell

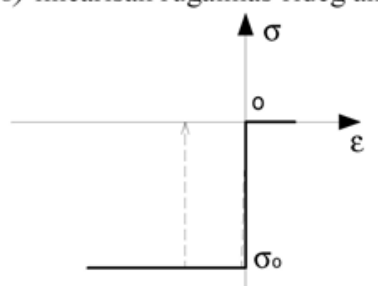

d) merev-tökéletesen képlékeny anyagmodell

4. ábra. Mérnöki anyagmodellek 
lét. Az alakváltozás lokalizációs tartománynak a mérete is anyagjellemzőként használandó. Mivel most a célunk a vályogfalazatnak, egyszerübben a vályogfal keresztmetszetének, a teherbírását meghatározni, ezért erre az adatra nem lesz szükségünk. A húzás okozta repedések szempontjából feltételezzük, ahol azok meg tudnak jelenni, folytonosan az ún. elkent repedésmodellnek megfelelően alakulnak ki.

\section{A VÁLYOGFALAZAT TEHERBÍRÁSA}

A vályogfalazat teherbírásának meghatározásakor állandó vastagságú fal $1 \mathrm{~m}$ hosszú szakaszát vizsgáljuk a fekvőhézagra merőleges külpontos nyomásra (5. ábra). Ahol $D$ a külpontos nyomóerő döféspontja (az $M$ hajlítónyomaték és az $N$ nyomóerő eredőjének a helye), $e$ a külpontosság.

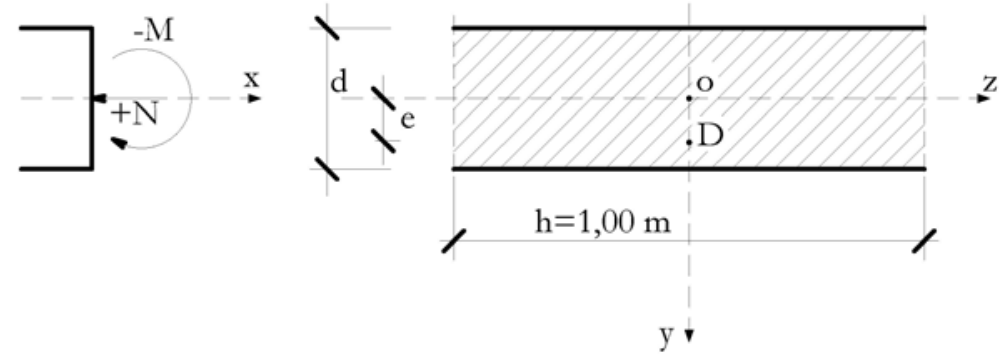

5. ábra. A vizsgált keresztmetszet

A falazat teherbírásán az adott külpontossághoz $(e)$ vagy normálerőhöz $(N)$ tartozó maximális nyomatékot $(M)$ értjük, ami nem feltétlenül a törési összenyomódáshoz vagy a feszültség-alakváltozás diagram más jellegzetes pontjához tartozik.

Adott normálerőhöz meghatározott nyomaték-görbület függvény általában maximummal rendelkező függvény. A keresztmetszet nyomaték-görbület és az anyag feszültség-összenyomódás függvényének kapcsolatát - a keresztmetszet szélső szálában kialakuló alakváltozás figyelembevételével - ábrázolva látható, hogy a maximá-

a)

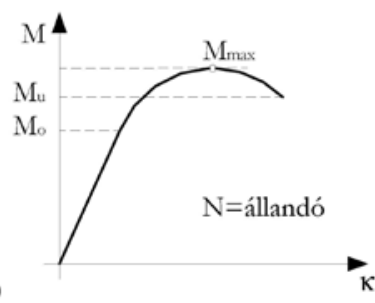

b)

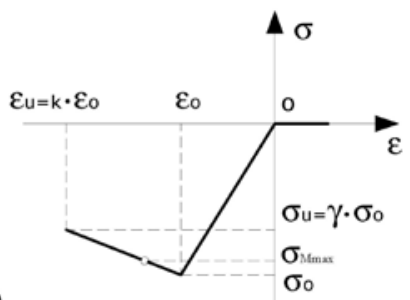

6. ábra. $a$ ) a keresztmetszet nyomaték-görbület függvénye, $b$ ) az anyagtörvény 
lis nyomaték általában az alakváltozásra fellágyuló ág valamely közbenső pontjához tartozik (6. ábra). A teherbírást az adott normálerőhöz tartozó maximális nyomatékkal adjuk meg, a nyomatéki maximum értéke azonban általában nem egyezik meg sem a rugalmas határhoz, sem a törési összenyomódáshoz tartozó, sem más elöre megadott feszültséghez vagy alakváltozáshoz tartozó nyomaték értékével.

A 6. ábra nyomaték-görbület függvényén bejelöltük azt a nyomatékot $\left(M_{o}\right)$, amely ahhoz az állapothoz tartozik, amikor a keresztmetszet szélső szálában a feszültség értéke a maximális $\left(\sigma_{\max }=\sigma_{o}\right)$. Az ábrán látható, hogy ebben az esetben a maximális nyomaték $\left(M_{\max }\right)$ értéke nagyobb, mint a maximális feszültséghez tartozó nyomaték $\left(M_{o}\right)$. A nyomaték-görbület függvény végpontjához tartozó nyomaték $\left(M_{u}\right)$ ahhoz az állapothoz tartozik, amikor a keresztmetszet szélső szálában az összenyomódás értéke a törési összenyomódással megegyezik $\left(\varepsilon_{\max }=\varepsilon_{u}\right)$. A 6 . ábrán a feszültség-összenyomódás függvény végpontjához tartozó nyomaték $\left(M_{u}\right)$ kisebb, mint a keresztmetszeten fellépő maximális nyomaték $\left(M_{\max }\right)$. Ebből az következik, hogy a teherbírást nem lehet minden esetben elöírt határállapotokkal megadni, mert a maximális nyomaték az alakváltozásra fellágyuló anyagmodell fellágyuló ágának valamely közbenső pontjához tartozhat. Természetesen bizonyos igénybevétel kombinációkra megváltozhat az imént említett jellegzetes nyomatékértékek viszonya (pl. $M_{\max }$ egybeeshet $M_{u}$-val), de ez elöre nem tudható (lásd [3]).

A keresztmetszet, vályogfalazat teherbírásának meghatározásakor a következő feltevéseket használjuk:

- A vályogfalazatnak nincs húzószilárdsága,

- A vályogfalazat nyomásra lineárisan rugalmas-lineárisan fellágyuló anyag, 3. ábra,

- Érvényes a Bernoulli-Navier-hipotézis, azaz a falazat keresztmetszetei az alakváltozás után síkok és önmagukkal egybevágóak maradnak.

Falazott szerkezetek számításakor szinte természetes, hogy a falazat húzószilárdságát elhanyagoljuk. A valóságban azonban, a habarcs vagy más kötőanyag nélkül épített falak kivételével, mindig van egy csekély húzószilárdsága a falazatnak. A terhelés folyamán, a húzófeszültség miatt megjelenő repedést vesszük figyelembe a húzószilárdság elhanyagolásával.

A repedés kialakulásának folyamatát (a teher-repedéshossz kapcsolatát) és a teherbírást is a törésmechanika elvei szerint kellene vizsgálnunk. A törésmechanika elvei szerint nem feszültség vagy alakváltozás, hanem energia-mérték a tönkremenetel feltétele. Felmerülhet a kérdés, hogy a húzószilárdság elhanyagolásával vizsgálva a „repedésterjedést” a biztonság javára közelítünk-e?

Bažant [2] vizsgálatai szerint, amennyiben sürü, sok repedés alakul ki, azaz a repedés nem lokalizálódik, koncentrálódik egy helyre, akkor az anyag húzószilárdsága elhanyagolható. A teherbírás a szilárdságtan elvei alapján határozható meg. A szárazon, alacsony falazóelemekből (sok, egymáshoz közeli fekvőhézaggal, azaz mesterséges repedéssel) falazott falra elméletileg is helyes a csak nyomásnak ellenálló anyagú szilárdságtani modellel történő vizsgálat. 
[2] alapján a vályoghabarccsal falazott, majdnem nulla húzószilárdságú vályogfalazat esetében feltételezzük, hogy a húzószilárdság nélküli modellel számított teherbírás a biztonság javára közelít.

A falazat összes lehetséges igénybevétel kombinációjához tartozó teherbírást, ellenállást teherbírási vonal segítségével adjuk meg [10, 11, 3$]$.

A teherbírási vonal azon összetartozó nyomaték-normálerő párok összessége, amely az adott normál erőhöz $(N)$, vagy adott külpontossághoz $(e)$ tartozó legnagyobb nyomatékot, illetve normál erő-nyomaték párt jelenti, függetlenül attól, hogy az alakváltozás eléri-e a törési összenyomódás értékét, vagy sem. Másként a teherbírási vonal az összes elöírt és lehetséges feszültség-alakváltozás állapothoz tartozó „állapotvonalak” burkológörbéje. Az ,állapotvonalak” az önkényesen elöírt feszültség vagy alakváltozás állapothoz tartozó igénybevétel kombinációk.

A teherbírási vonalat a fajlagos normálerő és fajlagos nyomaték függvényében adjuk meg, amelynek értelmezése a következő:

$$
\begin{aligned}
& \bar{N}=\frac{N}{h \cdot d \cdot \sigma_{o}} \\
& \bar{M}=\frac{M}{h \cdot d^{2} \cdot \sigma_{o}} .
\end{aligned}
$$

A teherbírási vonalat általában konvex görbének gondoljuk. Az általában használt anyagmodellek (4. ábra) esetében ez bizonyítható is. A fellágyuló, eső ágat is tartalmazó anyagtörvény esetében ez nem magától értetődő dolog. [13] szerint azonban fellágyuló, eső ággal rendelkező anyagtörvények esetén is konvex lesz a teherbírási vonal, ha az eső ág folytonos, nincs benne hirtelen ugrás. Így a meghatározandó teherbírási vonalnak is konvexnek kell lennie.

Az (5 és 6) szerinti normálerő és nyomatéki paraméterek bevezetésével a keresztmetszeti méretektől függetlenül állíthatók elő a teherbírási vonalak [8].

\subsection{TEHERBÍRÁSI VONAL ELÖÍRT ÁLLAPOTOKHOZ}

A teherbírási vonalat először az egyik szélső szálban előírt összenyomódás $\left(\varepsilon_{1}=\varepsilon_{u}\right)$ mint (határ)állapot alapján határozzuk meg. A jobban összenyomodó szélső szál és a semleges tengely távolságát jelöli. Ennek nagysága változó, lehet kisebb (a fal berepedt húzásra) és nagyobb is (a teljes falkeresztmetszet nyomott), mint a fal vastagsága. A lehetséges eseteket a 2. táblázatban foglaltuk össze. „1”-es esetnek neveztük azt, amikor a keresztmetszet berepedt állapotban van, „2”-sel, amikor a teljes keresztmetszet dolgozik. Ezen belül még két esetet különböztetünk meg aszerint, hogy a keresztmetszetben mekkora a fajlagos összenyomódás értéke. „A”-val jelöltük, ha van olyan keresztmetszetrész, ahol a fajlagos összenyomódás kisebb, mint $\varepsilon_{o}$ (a maximális feszültséghez tartozó alakváltozás érték). „B”-vel jelöltük, ha 
az előbbi alakváltozás értéket $\left(\varepsilon_{o}\right)$ a keresztmetszet minden pontjában meghaladja az összenyomódás. A rugalmas állapotban levő rész magasságát $b$-vel, míg az alakváltozás lágyult, nyomásra károsodott részt $a$-val jelöltük.

A 2. táblázatbeli esetek mindegyike olyan állapot, amelyekről úgy gondoljuk, hogy legalább néhány pontja közvetlenül a teherbírási vonallal, az ,állapotvonalak” burkolójával egybeesik.

2. táblázat. Az előírt állapotok és jellemzőik az elöírt állapotokhoz tartozó teherbírási vonalhoz

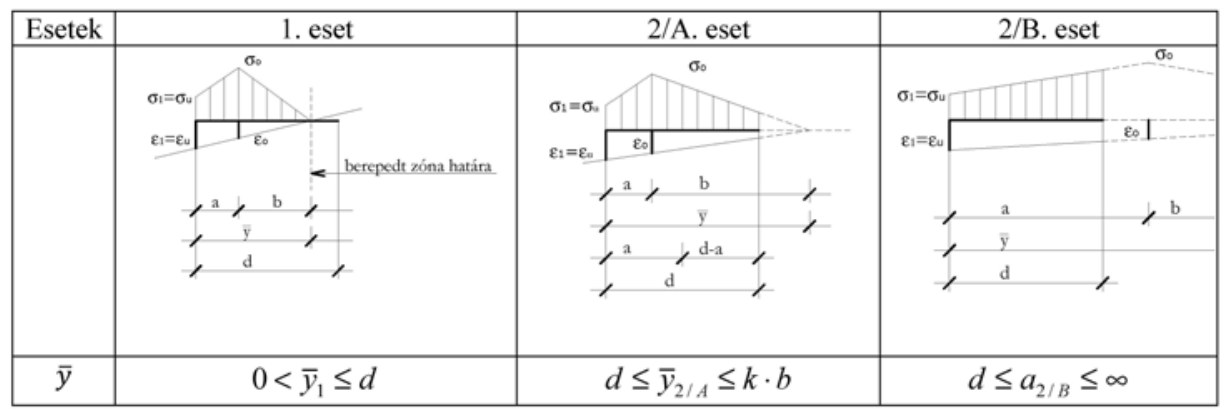

$\mathrm{Az}$ 1. esetben a keresztmetszet berepedt állapotban van és részben nyomásra is károsodott ( $a$ méret), a szélső szálban a feszültség értéke $\sigma_{u}$, az összenyomódás pedig maximális $\left(\varepsilon_{u}\right)$, lásd 3. ábra. A nyomóerő döféspontja a magidomon kívül van, mivel van berepedt rész. Ez az állapot addig tart, amíg az értéke el nem éri a keresztmetszet szélét. Ezután a 2. eset következik, melyben már a teljes falkeresztmetszet dolgozik.

A 2/A. esetben hasonlóan az előbbi esethez, a szélső szálban a feszültség értéke $\sigma_{u}$, az összenyomódás pedig maximális. A nyomóerő döféspontja a magidomon belül van, mivel nincs berepedt rész.

A 2/B. esetben az egész keresztmetszet anyaga károsodott nyomásra. A keresztmetszetben a feszültség sehol sem éri el a maximális értéket $\left(\sigma_{o}\right)$, annál kisebb; viszont az összenyomódás mindenütt nagyobb a maximális feszültséghez tartozó értéknél.

A 2. táblázat mindegyik esetéhez, a keresztmetszetre felírható vetületi és nyomatéki egyenértéküségi egyenletekből, analitikusan számíthatók a feszültségi ábrához tartozó igénybevételek [6], amelyek az ,állapotvonal” pontját jelentik.

Egy elöírt állapothoz tartozó ,állapotvonalat” a 7. ábra mutat be.

A 6. ábra szerint nem a maximális feszültséghez vagy összenyomódáshoz tartozik a legnagyobb teherbírás, hanem az alakváltozás lágyulási ág valamely más pontjához. Ha megrajzoljuk az alakváltozásra fellágyuló anyagmodell eső ágának különböző pontjaihoz tartozó alakváltozáshoz mint előírt állapotokhoz az ,állapotvonalakat", ezek egymást metsző vonalsereget eredményeznek. Vagyis különböző normálerőhöz tartozó nyomatéki teherbírás más-más elöírt állapothoz tartozik. A keresztmetszet teherbírási vonalát az összes lehetséges ,állapotvonal” burkolója jelenti. 


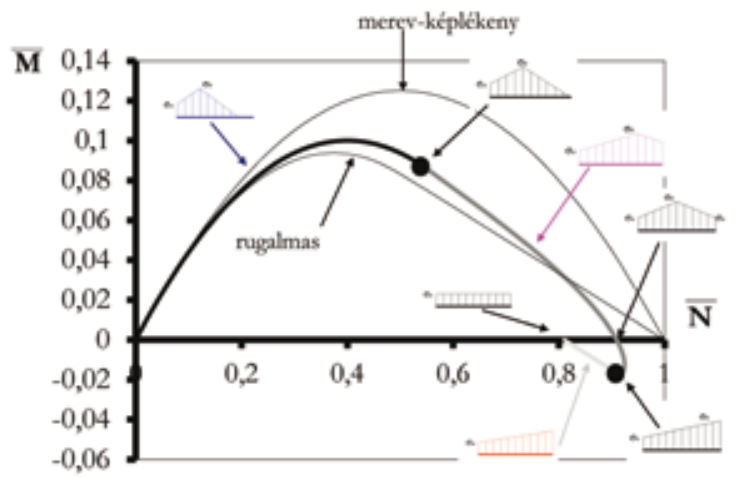

7. ábra. A keresztmetszet előírt állapotához tartozó teherbírási vonal $\left(\gamma=0,8, k=1,5, E_{o}=400 \mathrm{~N} / \mathrm{mm}^{2}\right)$

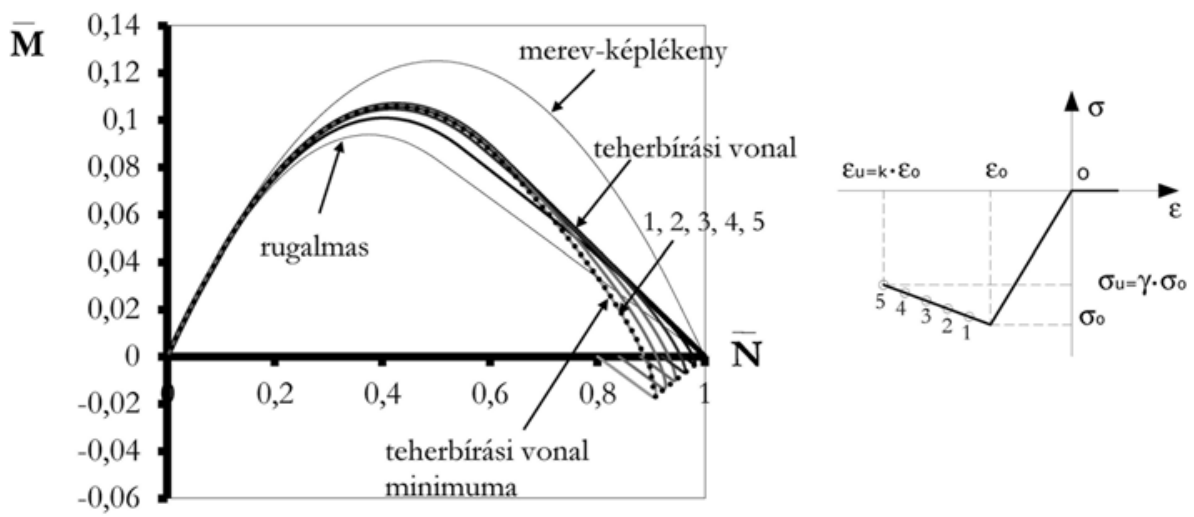

8. ábra. Az „állapotvonalak” $(1,2,3,4,5)$ burkolója a teherbírási vonal $\left(\gamma=0,8, k=1,5, E_{o}=400 \mathrm{~N} / \mathrm{mm}^{2}\right)$

$\mathrm{Az}$,állapotvonalak” seregéhez grafikusan lehet a burkoló görbét meghatározni. A 8. ábrán látható, hogy az, „állapotvonalak” egymást metszik és a teherbírási vonal, a burkoló, különböző szakaszain különböző állapotoknak megfelelő ,állapotvonalak" eredményezik a teherbírási vonalat.

Annak ellenére, hogy az anyagtörvény eső ággal rendelkezik, a tényleges teherbírási vonal konvex, [13]-nak megfelelően.

Az alakváltozásra fellágyuló anyagtörvényhez tartozó teherbírási vonal a rugalmas és a (tökéletesen) képlékeny állapothoz tartozó teherbírási vonalak között van. A nagyon kicsi nyomóerők kivételével jelentős az eltérés a három teherbírási vonal között. A képlékeny teherbírási vonal a biztonság kárára adja meg a teherbírást, a rugalmas pedig nagyon alulbecsüli, amennyiben a valós viselkedést az alakváltozásra fellágyuló anyagmodell írja le helyesen. 


\subsection{TEHERBÍRÁSI VONAL NYOMATÉK-GÖRBÜLET FÜGGVÉNY ALAPJÁN}

A továbbiakban olyan módszert mutatunk be, amely közvetlenül az ,állapotvonalak" burkoló görbéjét, a teherbírási vonalat adja meg. Tekinthetjük a normál erőt $(N)$ állandónak, és ehhez tartozóan határozzuk meg a keresztmetszet nyomaték-görbület függvényét, majd számítjuk az állandó normálerőhöz tartozó maximális nyomatékot. Tekinthetjük az erő helyét is, vagyis a külpontosságot (e) állandónak, és ehhez tartozóan számítjuk a keresztmetszet nyomaték-görbület függvényét, és a hozzátartozó maximális normálerő-nyomaték pár értékét. A továbbiakban a normál erőt $(N)$ veszszük állandónak a teherbírási vonal meghatározásakor.

A 3. táblázatban adtuk meg az összes lehetséges állapotot és a nekik megfelelö feszültségi ábrát. Két állapotot különböztettünk meg, úgymint a keresztmetszet berepedt (ezt 1-essel jelöltük), illetve ha a teljes keresztmetszet nyomott (ezt jelöltük 2-essel). Mind a károsodás és repedésmentes, károsodott és repedésmentes, mind a berepedt és károsodásmentes vagy károsodott állapotok figyelembevétele szükséges a nyomaték-görbület függvények meghatározásához.

Az 1/A. állapotban a keresztmetszet egy része nyomott és az anyag rugalmas állapotban van. Az 1/B. állapot esetén szintén csak a keresztmetszet egy része nyomott, viszont a nyomott anyag már részben károsodott.

A 2/A. állapotban a teljes keresztmetszet nyomott, viszont a szélső szálban a feszültség értéke nem éri el a maximumot $\left(\sigma_{o}\right)$, tehát a keresztmetszet rugalmas állapotban van. A 2/B. állapotban is a teljes keresztmetszet dolgozik, és a szélső szál összenyomódása meghaladja a maximális feszültséghez $\left(\sigma_{o}\right)$ tartozó fajlagos összenyomódás értéket $\left(\varepsilon_{o}\right)$, az anyag részben károsodott. Itt bevezetésre került a döfésponttal átellenes oldali szélső szál feszültsége $\left(\sigma_{2}\right)$. A 2/C állapotban szintén a teljes keresztmetszet nyomott, a szélső szál összenyomódása elérte a törési összenyomódás értékét $\left(\varepsilon_{u}\right)$, és teljes keresztmetszet anyaga károsodott nyomásra. A folyamat végét az jelenti, hogy a teljes keresztmetszeten kialakul az alakváltozási ág végpontjához tartozó összenyomódás $\left(\varepsilon_{u}\right)$, és feszültség $\left(\sigma_{u}\right)$.

A 3. táblázat mindegyik esetéhez analitikusan számítható a feszültségi ábrához tartozó nyomaték, adott görbület és nyomóerö esetén, amely a nyomaték-görbület függvény pontját jelenti.

A nyomaték-görbület $(M-\kappa)$ diagram megszerkesztésénél, állandó nagyságú normál erő mellett, a görbület értékét folyamatosan növelve meghatároztuk a lehetséges állapot jellegét. Ez a semleges tengely helyét megadó értéke alapján dönthető el. Az értéke a keresztmetszetre felírható vetületi egyenértéküségi egyenletből számítható. Ennek ismeretében a nyomaték már számítható a nyomatéki egyenértéküségi egyenletből. A számítás menetét az indokolja, hogy a normálerö, a nyomaték és a feszültségi ábra jellege is függ a görbület értékétől. Amennyiben a görbület, illetve a feszültségi ábra jellege ismertté válik, akkor a nyomaték és az is könnyen számítható. A számítások ellenőrzéséhez a szélső szál összenyomódását használtuk fel, amely sohasem haladhatja meg a legnagyobb összenyomódás $\varepsilon_{u}$ értékét. 
3. táblázat. A lehetséges állapotok a nyomaték-görbület függvények meghatározásához

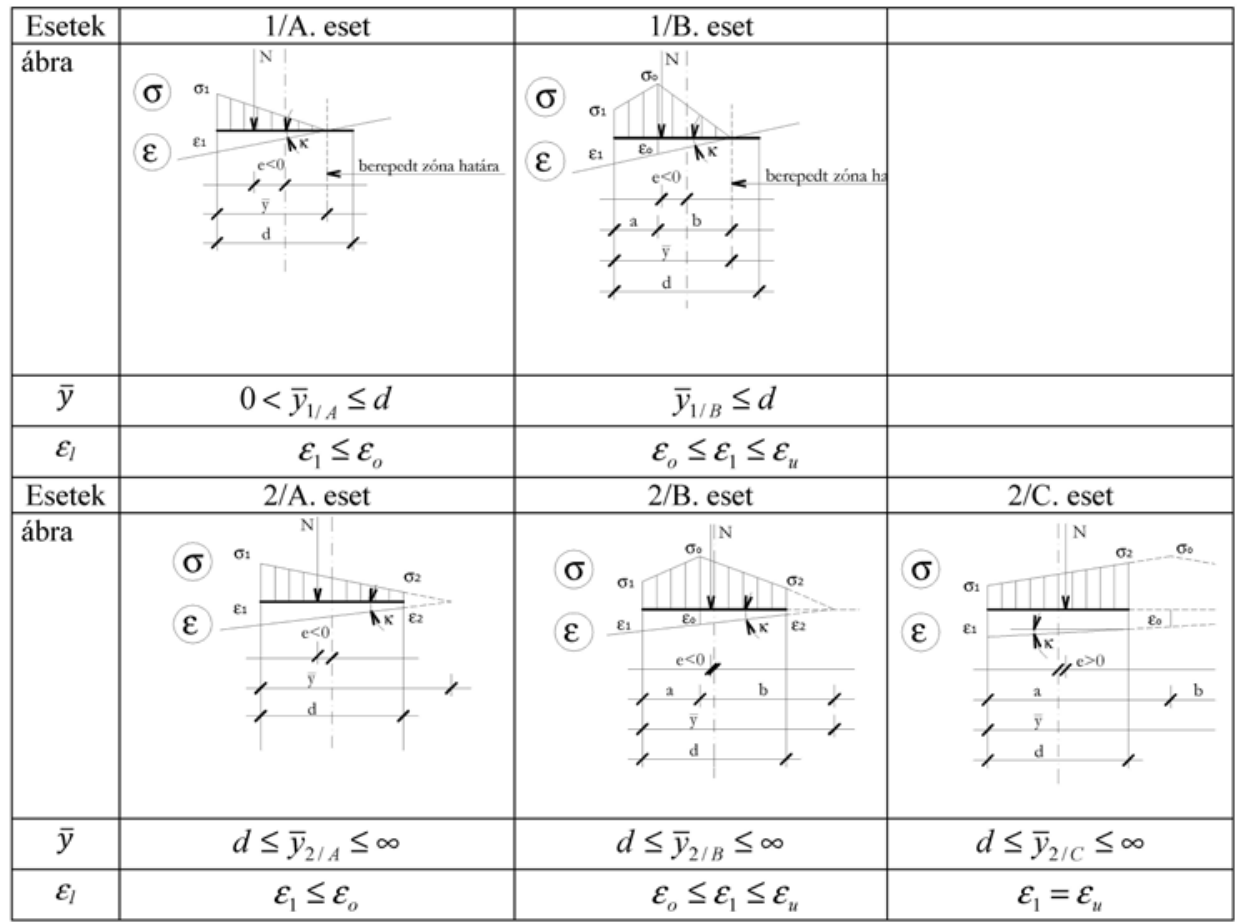

\subsubsection{A NYOMATÉK-GÖRBÜLET FÜGGVÉNYEK JELLEGZETESSÉGEI}

A nyomaték-görbület függvények jellege alapján kétféle viselkedést lehet megkülönböztetni. A rideg viselkedést, amely esetén a tönkremenetel hirtelen következik be, míg a duktilis viselkedés esetében a tönkremenetel nagy alakváltozás után következik be [11]. Az alakváltozásra fellágyuló anyagú falazatnál mindkét eset előfordul, illetve kiegészül más esetekkel is. Ezek az eső ágat is tartalmazó nyomaték-görbület függvények, amelyek viselkedését kvázi-ridegnek nevezhetjük.

A nyomaték-görbület függvények négy csoportra oszthatóak alakjuk szerint:

a) az első típus olyan monoton emelkedő függvény, amelyhez nagy deformáció tartozik, a tönkremenetel lassan következik be (jellegét tekintve duktilis a viselkedés) (9.a ábra),

b) a második típus pedig olyan monoton emelkedö függvény, amelyhez csak kis deformáció tartozik, a tönkremenetel hirtelen következik be (jellegét tekintve rideg a viselkedés) (9.b ábra), 
c) a harmadik típus egy felülről domború függvény, amely rendelkezik maximummal, illetve a függvény végpontján minimum értékkel (jellegét tekintve kvázirideg a viselkedés) (9.c ábra),

d) a negyedik esetben pedig a függvény hurok alakú, zárt görbe (jellegét tekintve kvázi-rideg a viselkedés) (9.d ábra).

a)

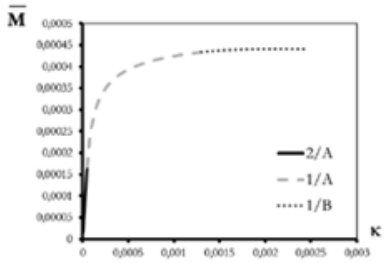

c) $\bar{N}=0,85$

$\overline{\mathbf{M}}$

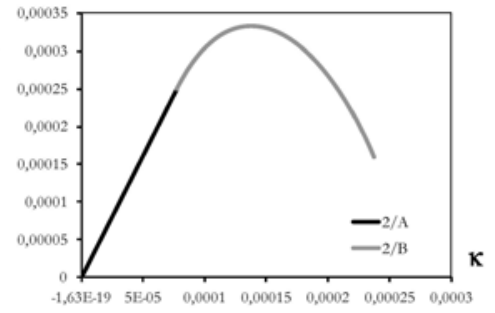

b) $\overline{\mathrm{M}}$

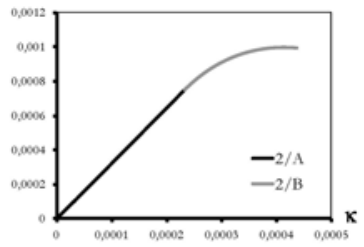

d) $\bar{N}=0,99$

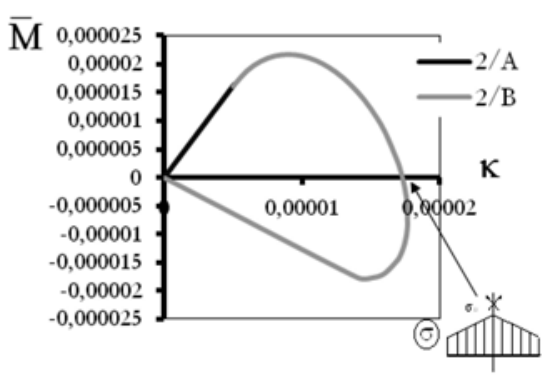

e)

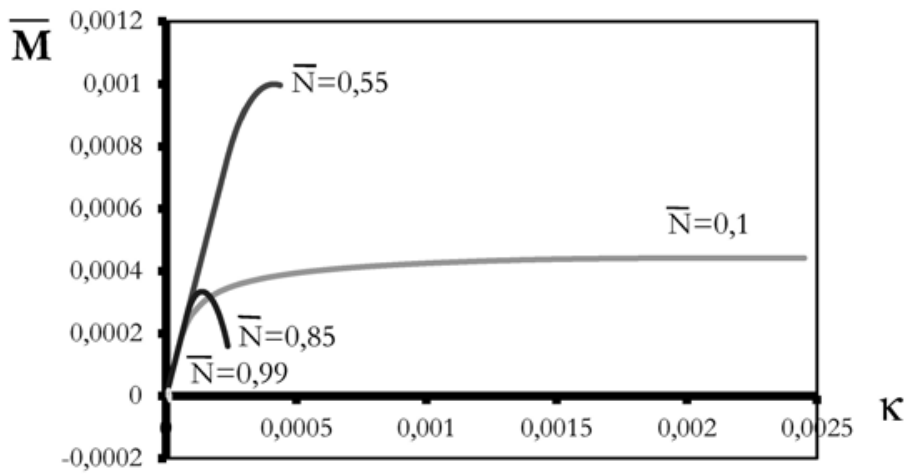

9. ábra. $a-d)$ Jellegzetes nyomaték görbület függvények a különböző fajlagos normálerökhöz, e) az $a-d$ ábrák együtt ábrázolva $\left(k=1,5, \gamma=0,8, E_{o}=400 \mathrm{~N} / \mathrm{mm}^{2}\right)$ 
A teherbírási vonal meghatározásakor az állandó nyomóerőt fokozatosan növelve megrajzoltuk a nyomaték-görbület függvényeket. Azt kaptuk, hogy a függvények alakja a fent említett sorrendben következik egymás után a nyomóerő növekedésével. Ami azt jelenti, hogy a kis nyomóerő esetén duktilisan viselkedik a keresztmetszet, majd a nyomóerőt növelve válik kvázi-rideggé, majd rideggé a viselkedés. Nagyobb nyomóerő esetén pedig ismét kezd nőni a tönkremenetelhez tartozó alakváltozás, viszont a törés hirtelen következik be.

$\mathrm{Az}$ anyagmodell paramétereinek hatását vizsgálva a következő megállapítások tehetök:

a) a kitüntetett összenyomódások arányának $(k)$ értéke minél kisebb, annál nagyobb nyomóerő értékig viselkedik duktilisan az anyag, és annál nagyobb a minimális nyomaték értéke,

b) nagy $k$ érték esetén már kisebb nyomóerőnél lesz rideg a viselkedés, és a negatív nyomatékok abszolút értékben kisebbek,

c) a kitüntetett feszültségek aránya $(\gamma)$ minél kisebb, annál inkább rideg a tönkremenetel, ugyanakkor a negatív nyomaték abszolút értékben annál nagyobb, és annál kisebb normálerő esetén jelenik meg.

Az egyes normálerőhöz megrajzolt $M-\kappa$ görbék rendelkeznek maximum, illetve minimum ponttal, amelyeket numerikusan határoztunk meg. Az így kapott értékek adják a teherbírási vonalat (8. ábra). A folytonos vonal a nyomaték-görbület függvény maximumpontjaiból áll, ez a keresztmetszet teherbírása, a pontozott vonal a teherbírás „,minimuma”, ebben az esetben a nyomaték-görbület függvény végét ábrázoltuk. Ekkor a szélső szálban az összenyomódás eléri a törési összenyomódás értékét $\left(\varepsilon_{u}\right)$.

\subsection{A TEHERBÍRÁSI VONAL VÁLTOZÁSA A $k$ FÜGGVÉNYÉBEN}

A $k$, vagyis a maximális feszültségez tartozó összenyomódás $\left(\varepsilon_{o}\right)$, és a törési öszszenyomódás $\left(\varepsilon_{u}\right)$ aránya módosítja a teherbírási vonal jellegét. Minél nagyobb a $k$ értéke, annál közelebb kerül a teherbírási vonal a képlékeny teherbírási vonalhoz, és minél kisebb, annál közelebb lesz a rugalmas teherbírási vonalhoz (10. ábra). A képlékeny teherbírási vonalat alulról, a rugalmas teherbírási vonalat felülről közelíti a fellágyuló anyagmodellhez tartozó teherbírási vonal. A $k$ értékének egyenletes növelése esetén a teherbírási vonal egyre kisebb mértékben növekszik, és csak nagyon nagy $k$ érték esetén közelíti meg a képlékeny teherbírási vonalat. Ebből az következik, hogy a fellágyuló anyagmodell $k$ paraméterének pontos meghatározásának az egyhez közeli értékek esetén van nagyobb jelentősége, hiszen ekkor a teherbírási vonal kis $k$ érték különbségek esetén is jelentősen megváltozik. 
$\overline{\mathbf{M}}$
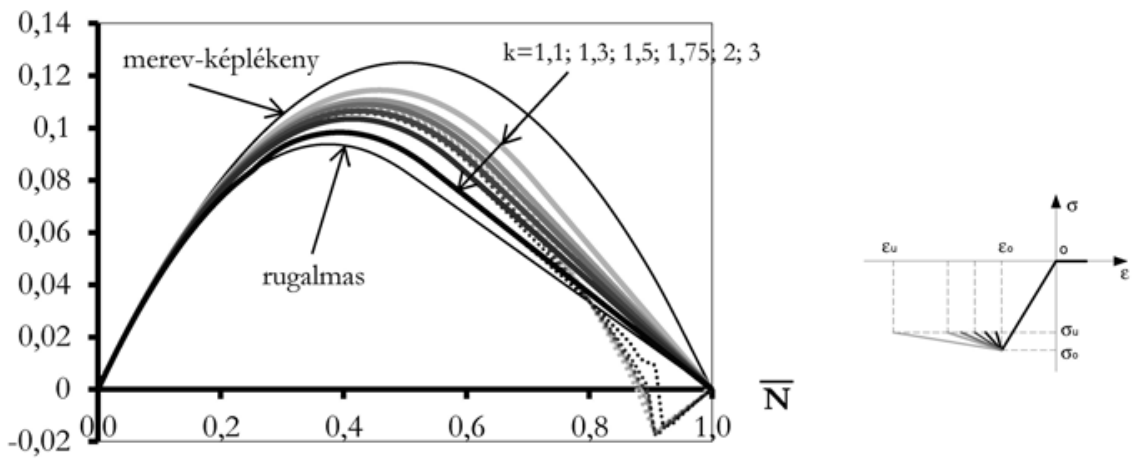

10. ábra. Különbözö $k$ értékekhez tartozó teherbírási vonalak, a $\gamma=0,8=$ állandó, $k=1,1 ; 1,3 ; 1,5 ; 1,75 ; 2,0 ; 3,0 ;\left(E_{o}=400 \mathrm{~N} / \mathrm{mm}^{2}\right)$

\subsection{A TEHERBÍRÁSI VONAL VÁLTOZÁSA A $\gamma$ FÜGGVÉNYÉBEN}

A $\gamma$, vagyis a maximális feszültség és az alakváltozásra lágyuló ág végéhez tartozó feszültség arányának vizsgálatakor azt figyelhetjük meg, hogy minél nagyobb a $\gamma$ értéke, a teherbírás annál nagyobb. Arányosan csökkentve a $\gamma$ értékét a teherbírási vonalak közötti különbség egyre kisebb lesz. A nagy $\gamma$ értékek esetén a képlékeny, a kisebb $\gamma$ értékek esetében pedig a rugalmas teherbírási vonalhoz esnek közelebb a teherbírási vonalak. A teherbírási vonal minimuma, abszolút értékben, a kicsi $\gamma$ értékekhez tartozóan nagyobb, és nagyobb nyomóerő tartományban érvényesül. Ebből azt a következtetést lehet levonni, hogy az anyagmodell felvételekor a nagy $\gamma$ esetén fontos a pontos érték meghatározása, míg kisebb $\gamma$ értékeknél a kis változás nem jelent nagy különbséget a teherbírási vonal értékében.
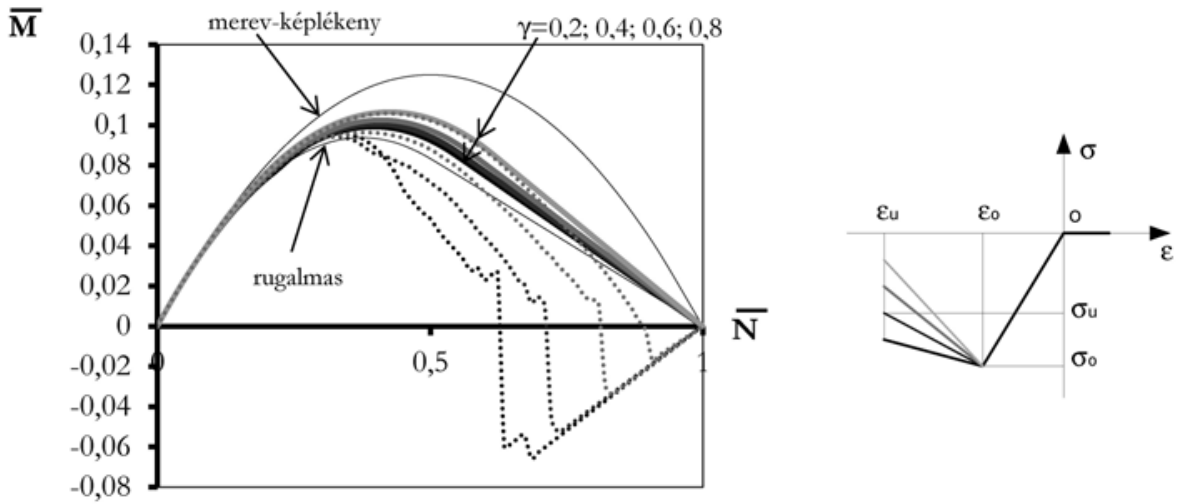

11. ábra. Különböző $\gamma$ értékekhez tartozó teherbírási vonalak, a $k=1,5=$ állandó, $\gamma=0,2 ; 0,4 ; 0,6 ; 0,8,\left(E_{o}=400 \mathrm{~N} / \mathrm{mm}^{2}\right)$ 


\subsection{A TEHERBÍRÁSI VONAL MAXIMUMA}

Az alakváltozásra fellágyuló anyagú keresztmetszet teherbírási vonalának maximuma is, a lineárisan rugalmas anyagú és a merev-képlékeny anyagú keresztmetszetekhez hasonlóan, a keresztmetszet vastagságának negyedében lévő külpontossághoz tartozik.

A teherbírási vonal maximumához tartozó feszültségi állapot kétféle lehet. Nagyon rövid $(k \leq 1,1 ; \gamma \geq 0,8)$ alakváltozásra fellágyuló ág esetén az $1 / \mathrm{A}$ jelü állapot (lásd a 3. táblázatban) (a keresztmetszet berepedt, és az $\varepsilon_{1} \leq \varepsilon_{\mathrm{o}}$ ). Ha az alakváltozásra fellágyuló ág hosszabb $(k>1,1 ; \gamma<0,8)$, akkor pedig az 1/B jelü (lásd a 3.táblázatban) állapot (a keresztmetszet berepedt, és az $\varepsilon_{o} \leq \varepsilon_{1} \leq \varepsilon_{u}$ ).

Az állítás bizonyítását, hogy az alakváltozásra fellágyuló anyag esetén is a teherbírási vonal maximumához tartozó külpontosság a favastagság negyede, Sipos A. Á. ötlete alapján [15] végeztük el.

Bizonyítás az 1/A jelü állapot esetében (12. ábra):

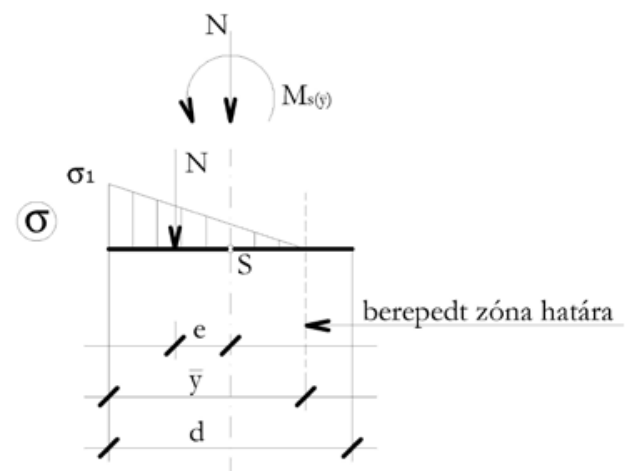

12. ábra. $1 / \mathrm{A}$ jelü állapot. Jelölések

Ha a feszültségi ábra 1/A állapot szerinti (12. ábra), akkor a normálerő:

$$
N_{(\bar{y})}=\frac{\sigma_{1} \cdot \bar{y}}{2} .
$$

A hajlítónyomaték pedig:

$$
M_{S(\bar{y})}=\frac{\sigma_{1} \cdot \bar{y}}{2} \cdot\left(\frac{d}{2}-\frac{\bar{y}}{3}\right) .
$$

Az egyenletekben a $\sigma_{1} \leq \sigma_{\mathrm{o}}$ változó paraméter. 
A nyomaték függvény maximuma:

$$
\begin{gathered}
\frac{d M_{S(\bar{y})}}{d \bar{y}}=\frac{\sigma_{1} \cdot d}{4}-\frac{\sigma_{1} \cdot \bar{y}}{3}=0, \\
\text { mivel } \sigma_{1} \neq 0, \text { ezért } \quad \bar{y}=\frac{3}{4} d .
\end{gathered}
$$

Behelyettesítve ezt a (7) és (8) képletekbe, majd a külpontosságot meghatározva:

$$
e=\frac{M_{S(\bar{y})}}{N_{(\bar{y})}}=\frac{\frac{\sigma_{1} \cdot \bar{y}}{2} \cdot\left(\frac{d}{2}-\frac{\bar{y}}{3}\right)}{\frac{\sigma_{1} \cdot \bar{y}}{2}}=\frac{d}{2}-\frac{d}{4}=\frac{d}{4} .
$$

Bizonyítás az 1/B jelü állapot esetében (13. ábra):

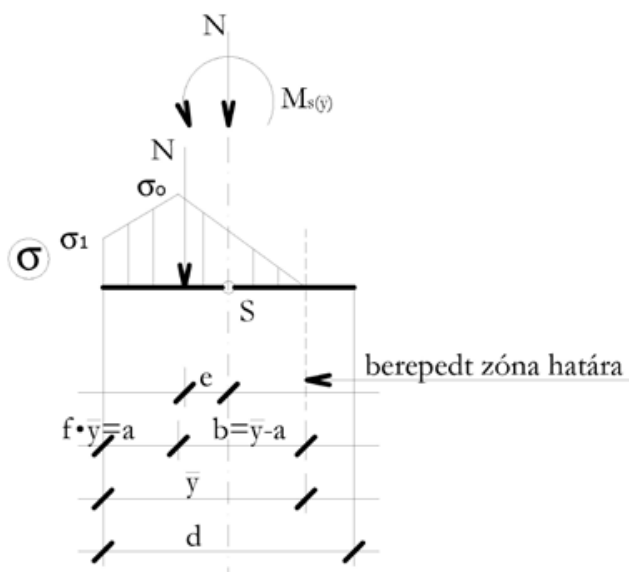

13. ábra. 1/B jelü állapot. Jelölések

Ha a feszültségábra 1/B állapot szerinti, akkor a normálerő:

$$
N_{(\bar{y})}=\frac{\sigma_{1} \cdot a}{2}+\frac{\sigma_{o} \cdot \bar{y}}{2} \text {. }
$$

A hajlítónyomaték pedig:

$$
M_{S(\bar{y})}=\sigma_{1} \cdot\left(\frac{d}{4}-\frac{a}{6}\right) \cdot a+\sigma_{o} \cdot\left(\frac{d}{4}-\frac{a}{6}\right) \cdot \bar{y}-\frac{\sigma_{o} \cdot \bar{y}^{2}}{6} .
$$


Az egyenletekben a $\sigma_{1}$ és $a$ paraméter. $\sigma_{\mathrm{u}} \leq \sigma_{1} \leq \sigma_{0} ; 0<a<d$.

Legyen:

$$
a=f \cdot \bar{y}, \quad f<1 .
$$

Ekkor a normálerő (12) és nyomaték (13) képlete:

$$
\begin{gathered}
N_{(\bar{y})}=\left(\sigma_{1} \cdot f+\sigma_{o}\right) \cdot \frac{\bar{y}}{2} \\
M_{S(\bar{y})}=\sigma_{1} \cdot f \cdot \bar{y} \cdot\left(\frac{d}{4}-\frac{f \cdot \bar{y}}{6}\right)+\sigma_{o} \cdot \bar{y} \cdot\left(\frac{d}{4}-\frac{\bar{y}}{6} \cdot(f+1)\right) .
\end{gathered}
$$

A nyomatékfüggvény maximumának a helye, ha $f=$ állandó:

ebböl

$$
\begin{gathered}
\frac{d M_{S(\bar{y})}}{d \bar{y}}=\left(\sigma_{1} \cdot f+\sigma_{o}\right) \cdot \frac{d}{4}-\left(\frac{\sigma_{1} \cdot f^{2}}{3}+\frac{\sigma_{o} \cdot(f+1)}{3}\right) \cdot \bar{y}=0, \\
\bar{y}=\frac{\left(\sigma_{1} \cdot f+\sigma_{o}\right) \cdot \frac{d}{4}}{\frac{\sigma_{1} \cdot f^{2}}{3}+\frac{\sigma_{o} \cdot(f+1)}{3}} .
\end{gathered}
$$

Behelyettesítve a (15) és (16) képletekbe, majd a külpontosságot meghatározva:

$$
e=\frac{M_{S(\bar{y})}}{N_{(\bar{y})}}=\frac{\left(\sigma_{1} \cdot f+\sigma_{o}\right) \cdot \frac{d}{2}-\frac{\left(\sigma_{1} \cdot f+\sigma_{o}\right) \cdot \frac{d}{4}}{\frac{\sigma_{1} \cdot f^{2}}{3}+\frac{\sigma_{o} \cdot(f+1)}{3}} \cdot\left(\frac{\sigma_{1} \cdot f^{2}}{3}+\frac{\sigma_{o} \cdot(f+1)}{3}\right)}{\left(\sigma_{1} \cdot f+\sigma_{o}\right)}=\frac{d}{2}-\frac{d}{4}=\frac{d}{4} .
$$

függetlenül $a$, illetve $f$ és $\sigma_{u} \leq \sigma_{1} \leq \sigma_{o}$ értékétől.

A bizonyítás érvényes lineárisan rugalmas, lineárisan rugalmas-tökéletesen képlékeny és lineárisan rugalmas-képlékeny korlátozott alakváltozású esetekre is, mivel $k$ és $\gamma$ változtatásával a fellágyuló anyagmodell megadja a fenti anyagtörvényeket is.

A 14. ábrán a különböző alakváltozásra fellágyuló-, a lineárisan rugalmas-, és a lineárisan rugalmas-tökéletesen képlékeny anyagmodellhez tartozó teherbírási vonalakhoz berajzoltuk a teherbírási vonal maximumát. Jól látszik, hogy a maximumok rajta vannak az $e=d / 4$ külpontosságnak megfelelö egyenesen. 


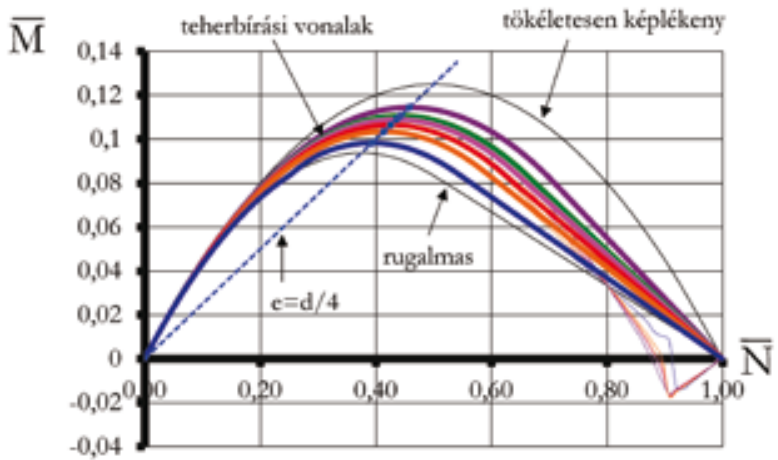

14. ábra. Teherbírási vonal maximuma az $e=d / 4$-hez tartozó egyenesen van. $\gamma=$ állandó $=0,8 ; k=$ változó $(k=1,1 ; 1,3 ; 1,5 ; 1,75 ; 2,0 ; 3,0), E_{o}=400 \mathrm{~N} / \mathrm{mm}^{2}$

\subsection{AZ ALAKVÁLTOZÁSRA FELLÁGYULÓ ÁG HATÉKONY HOSSZA}

Számításokat végeztünk az alakváltozásra fellágyuló ág és a falazat keresztmetszetének teherbírási vonala közötti összefüggés megállapítására. Megvizsgáltuk, hogy az alakváltozásra fellágyuló ágon végighaladva mely ponthoz (mint korlátozott alakváltozáshoz) tartozik a falazat keresztmetszet teherbírási vonalának pontja, azaz a nyomaték-görbület függvénynek a maximuma. Azt találtuk, hogy egy határon túl már nem befolyásolja a teherbírási vonalat az alakváltozásra fellágyuló ág hossza (15. ábra). Az alakváltozásra fellágyuló ág hatékony hosszának $\left(\varepsilon_{\text {ef }}>\varepsilon_{\mathrm{o}}\right)$ neveztük el azt a legnagyobb alakváltozást, amelyikhez még tartozik teherbírási vonal pont, azaz nyomaték-görbület függvény maximum.

A lineárisan rugalmas-tökéletesen képlékeny anyagú teherbírási vonal esetén is értelmezhető a hatékony alakváltozás, amelynek elméleti értéke végtelen.

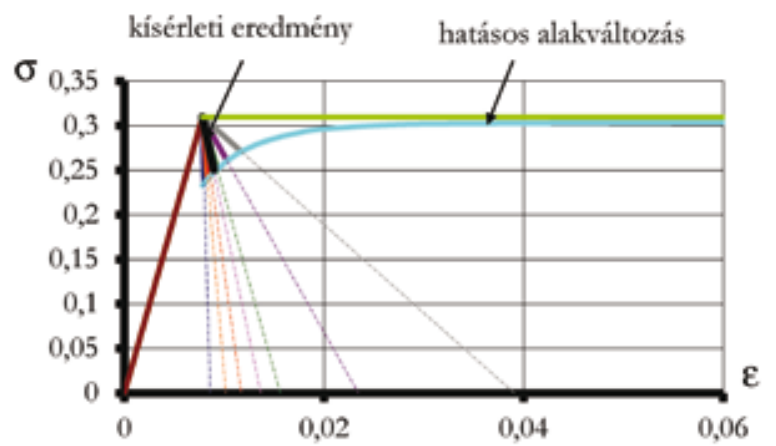

15. ábra. A fellágyuló ág hatékony hossza. (Az eső ág folytonos vonala a hatékony hosszat jelöli, a szaggatott vonal pedig a teherbírást már nem befolyásoló $\sigma-\varepsilon$ ábra szakaszt)

$\left(k=1,1453, \gamma=0,8105, c=1,304, E_{o}=400 \mathrm{~N} / \mathrm{mm}^{2}, \varepsilon_{o}=0,007809\right)$ 
A kísérletek [5, 6] során mért eső ág átlagos hossza gyakorlatilag ,egybeesik” a számítással meghatározható alakváltozással (15. ábra), azaz a kimért eső ág a számított hatékony alakváltozással azonos.

A kísérleteket hidraulikus terhelő berendezéssel végeztük. Az ilyen berendezés addig alkalmas az eső ág stabil kimérésére, amíg a tehercsökkenés miatt visszaáramló olaj sebessége összhangban van a tehercsökkenés sebességével, azaz elég lassú a tehercsökkentés igénye. Egyébként „,tehervezéreltté” válik a rendszer, és összeomlik a kísérleti elem, mivel már az eső ág jellemzi a viselkedését. A kísérletek során kimért eső ág átlagos hossza esik egybe a számított hatékony hosszal. A hatékony hossz nagyságú eső ágszakasz, külpontos nyomás esetén, a nyomaték-görbület függvény maximuma előtti szakaszt, tehát annak csak az emelkedő, stabil szakaszát befolyásolja. Azt állítjuk, hogy ez az oka a hatékony hossz kísérleti kimérhetőségének.

\subsection{A MAGIDOM FELLÁGYULÓ ANYAG ESETÉN}

Lineárisan rugalmas anyag esetén egy keresztmetszet magidomának határa azon nyomóerő döféspontok mértani helye, ahol müködő erő esetén a semleges tengely érinti a keresztmetszetet [10]. Rugalmas anyagú téglalap keresztmetszet esetén a magidom mérete föirányú külpontosság esetén $k_{y}=d / 6$. Fal esetén nem magidomról, hanem magsávról lehet beszélni, mivel a fal terhe megoszló teher $(N[\mathrm{kN} / \mathrm{m}])$ (16. ábra). A 16. ábrán, a metszeten jelölt „D” pont, a keresztmetszeten természetesen egy vonal, a tehernek megfelelöen, jelöli a magsáv határát.

A magidom, magsáv jellemzője, hogy a magidomon, magsávon belül müködő nyomóerő esetében a teljes keresztmetszet nyomott lesz. Ez a tulajdonság segít abban, hogy meghatározzuk a tökéletesen-képlékeny anyagú keresztmetszet magidomát. Ekkor a magidom egy, a keresztmetszet súlypontjával egybeeső ponttá zsugorodik, mivel csak ekkor nyomott az egész keresztmetszet tökéletesen-képlékeny anyag esetén.

Alakváltozásra fellágyuló anyag esetén a magsáv mérete függ a normálerőtől $(N)$, valamint az alakváltozásra fellágyuló ág hosszától $(k)$ és meredekségétől $(\gamma, c)$ is.

A magsáv határa $d / 12$ és $d / 6$ közé esik, attól függően, hogy hogyan változik az alakváltozásra lágyuló ág meredeksége és hossza. A magsáv határának változásában megfigyelhető, hogy minél nagyobb az alakváltozási ág hossza, vagyis minél na-

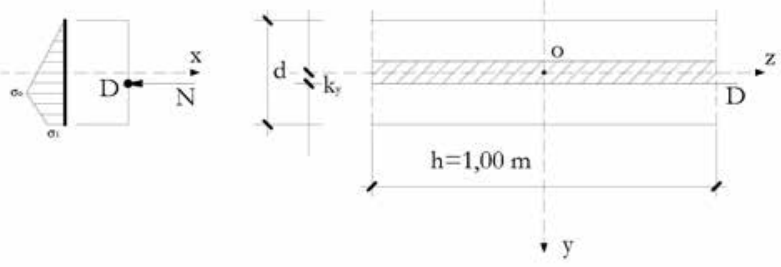

16. ábra. A falkeresztmetszet magsávja 
gyobb a $k$ paraméter értéke, annál kisebb a magsáv mérete. A $\gamma$ paraméter $\left(\sigma_{\imath} / \sigma_{o}\right.$ arányának) nagysága is befolyásolja a magsáv méretét. Minél kisebb a $\gamma$ értéke, annál nagyobb a magsáv mérete.

A magsáv méretének meghatározásakor négy eltérő szakaszát lehet megkülönböztetni a teherbírási vonalnak a normálerő változásával.

Az első szakasz az $\bar{N}=0,5$ értékig tart. Ebben a szakaszban a magsáv mérete megegyezik a tökéletesen rugalmas anyagú keresztmetszet magsávjának méretével, ez a keresztmetszet magasságának hatoda $\left(k_{y}=d / 6\right)$. A 17.a ábrán látható a $\bar{N}=0,3$ fajlagos normálerő szintjéhez tartozó nyomaték-görbület függvény és a teherbírási vonal. A bal oldali ábrán folytonos vonal jelöli azt, hogy a keresztmetszet repedésmentes, a szaggatott vonal pedig azt, hogy a keresztmetszet berepedt állapotban van. A jobb oldali ábrán látható, hogy a keresztmetszet berepedése már jóval korábban bekövetkezik, mint a teherbírási vonal elérése, tehát a keresztmetszet teherbírásának kimerülését már korán repedés jelzi.

A második szakaszban (17.b ábra) a magsáv mérete már nem állandó, hanem fokozatosan csökken a normálerő növekedésével. Egy állandó normálerőszintet vizsgálva az tapasztalható, hogy a keresztmetszet a teherbírási vonal elérése előtt bereped, de a repedésmentes állapothoz tartozó teherbírás közel van a keresztmetszet teherbírásához. A repedés megjelenése gyakorlatilag a teherbírás kimerülését jelenti.

A harmadik szakaszban (17.c ábra), állandó normálerő esetén, a teherbírási vonal eléréséig nem reped be a keresztmetszet, csak a nyomaték-görbület függvény eső ága mentén jelenik meg a repedés. Ekkor a teherbírás kimerülését nem jelzi előre repedés. A második és harmadik szakasz határa annál a nyomóerőnél - teherbírási vonal pontnál - van, amelyiknél a semleges tengely éppen érinti a keresztmetszetet. A nyomaték-görbület függvénynek a maximum pontja egybeesik a repedésmentes állapot végével, ugyanakkor a berepedt állapot kezdetével. A második és harmadik szakasz határa nem állandó, függ az alakváltozásra fellágyuló ág paramétereitől.

A negyedik szakaszban (17.d ábra) a keresztmetszet nem reped be, még a nyomaték-görbület függvénynek az eső ága mentén sem. A teherbírás kimerülését nem jelzi elöre repedés.

A 17. ábrán a teherbírási vonalakba berajzoltuk a repedésmentes állapot teherbírási vonalát. Ez az $\bar{N}=0,5$ határáig lineáris, utána a teherbírási vonal eléréséig harmadfokú függvény [6]. A teherbírási vonal elérése után szaggatott vonallal jelöltük a repedésmentes állapot teherbírási vonalát. Ennek a szaggatott vonalnak az elérése jelzi, hogy az eső ágon a repedések bezáródnak. 

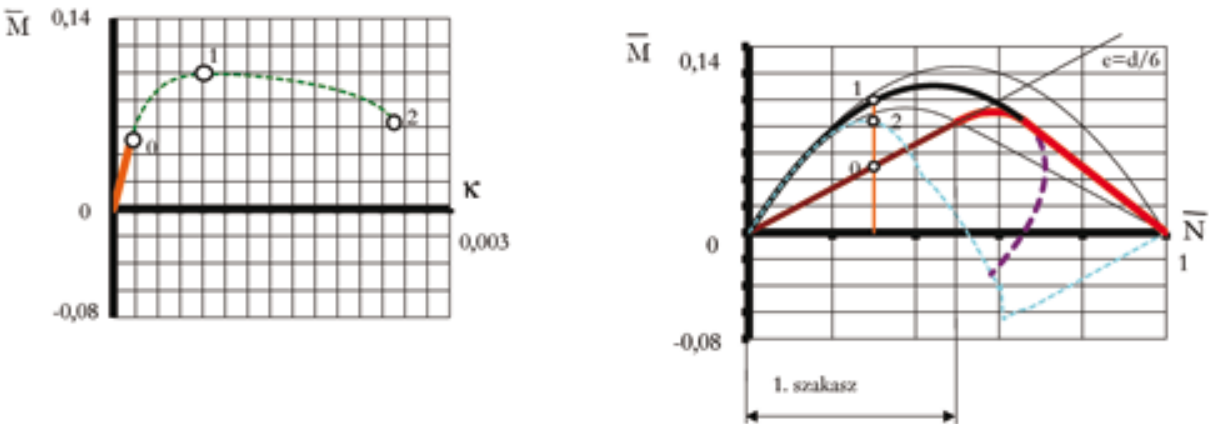

17.a ábra. Jobb oldal: $\bar{M}-\kappa$, ha $\bar{N}=0,3$; bal oldal: $\bar{N}=0,3-$ hoz tartozó $\bar{M}$ változása a teherbírási vonalban bejelölve
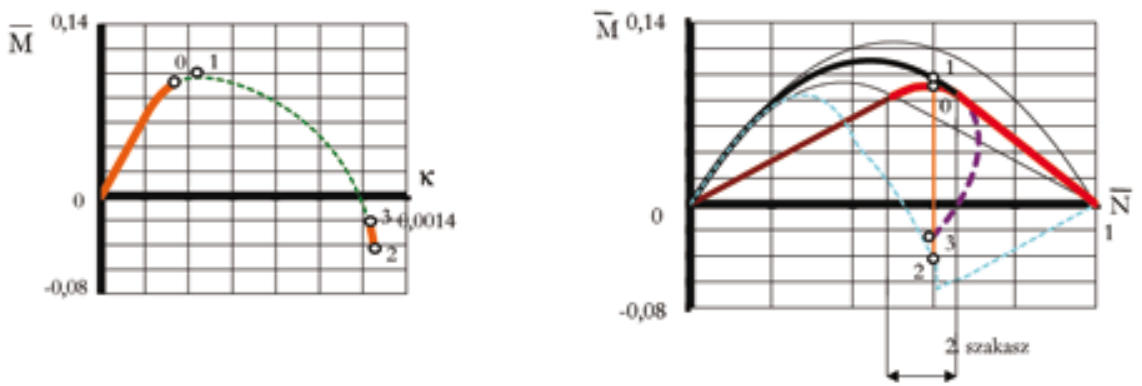

17.b ábra. Jobb oldal: $\bar{M}-\kappa$, ha $\bar{N}=0,6$; bal oldal: $\bar{N}=0,6$-hoz tartozó $\bar{M}$ változása a teherbírási vonalban bejelölve
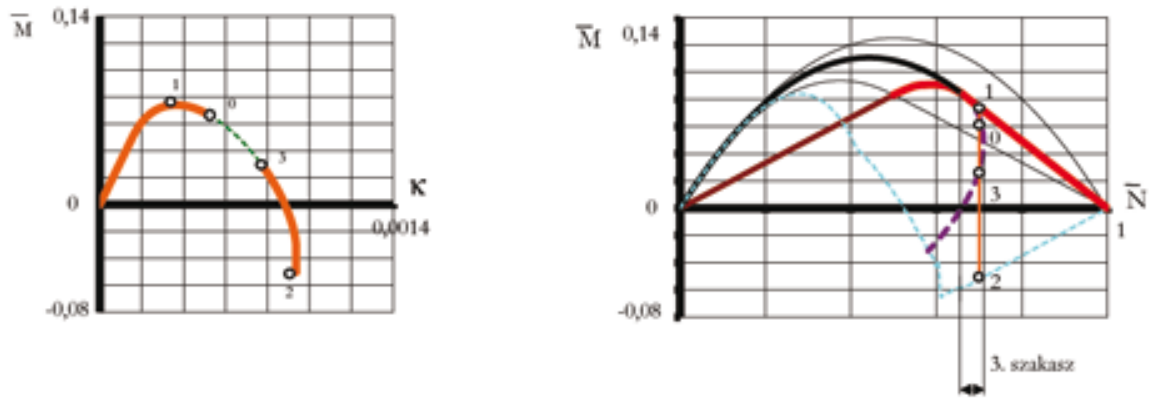

17.c ábra. Jobb oldal: $\bar{M}-\kappa$, ha $\bar{N}=0,7$; bal oldal: $\bar{N}=0,7$-hoz tartozó $\bar{M}$ változása a teherbírási vonalban bejelölve 

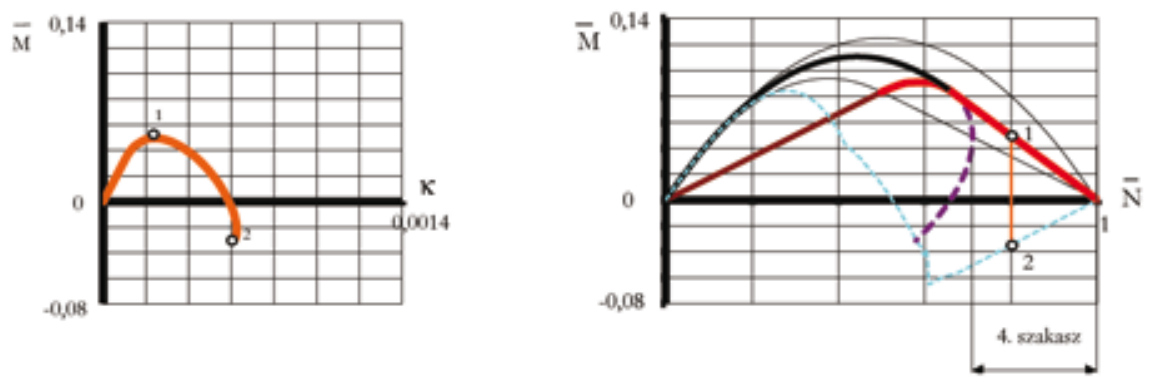

17.d ábra. Jobb oldal: $\bar{M}-\kappa$, ha $\bar{N}=0,8$; bal oldal: $\bar{N}=0,8$-hoz tartozó $\bar{M}$ változása a teherbirási vonalban bejelölve

17. ábra. Nyomaték-görbület függvény és a teherbírási vonal kapcsolata $(\gamma=0,2 ; k=5)$, jelölések: 0 - a keresztmetszet bereped, 1 - a keresztmetszet teherbírása, 2 - törési összenyomódáshoz tartozó nyomaték, 3 - a repedés bezáródik

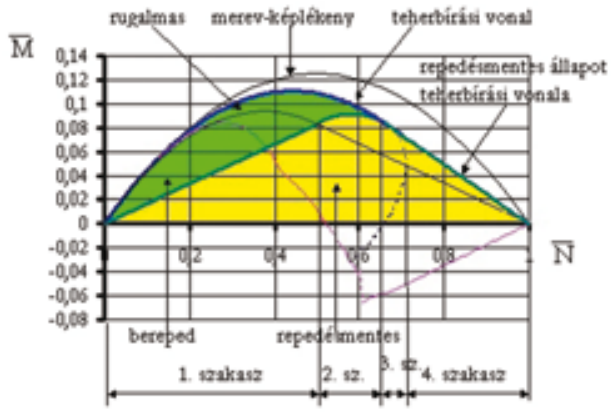

18. ábra. A repedésmentes teherbírási vonal és a teherbírási vonal kapcsolata $\left(k=5, \gamma=0,2, E_{o}=400 \mathrm{~N} / \mathrm{mm}^{2}\right)$

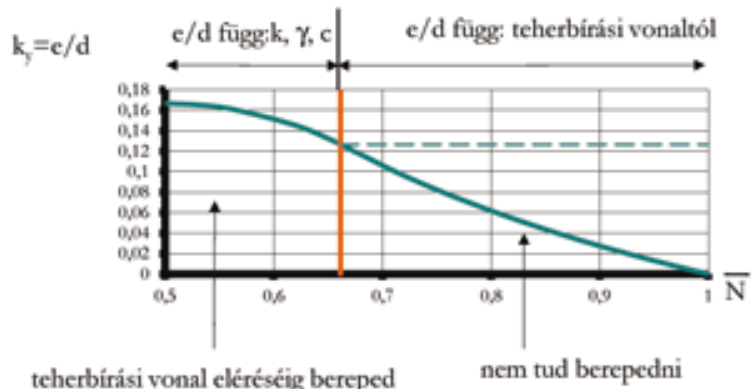

19. ábra. A repedésmentes állapotot jelző külpontosság változása a nyomóerő növekedésével, a magsáv mérete. A szaggatott vonallal jelzett nyomóerö tartományban a keresztmetszet nem tud berepedni a teherbírási vonal eléréséig, itt a folytonos vonal az adott normáleröhöz tartozó maximális külpontosságot mutatja. $\left(k=5, \gamma=0,2, E_{o}=400 \mathrm{~N} / \mathrm{mm}^{2}\right)$ 
A 18. ábra mutatja a teherbírási vonal repedésmentes és berepedt tartományait a nyomaték-görbület függvények eső ágát is figyelembe véve. Az ábrán, a fajlagos normálerő függvényében, jól elkülöníthető a falazat eltérő viselkedését mutató négy szakasz. A 18. ábrán a teherbírási vonalba berajzoltuk a repedésmentes állapot teherbírási vonalát is.

A 19. ábrán a keresztmetszet repedésmentes állapotának határához tartozó külpontosság értékeket ábrázoltuk a normálerő függvényében. Ha $\bar{N} \leq 0,5$, akkor a rugalmas magsáv méret a repedésmentes állapotot jelző külpontosság. (Ez a maximális magsáv méret, $k_{y \max }=d / 6$.) Ezután, ha $\bar{N}>0,5$, akkor a repedésmentes állapothoz tartozó külpontosság csökken a normálerő növekedésével. Amikor a repedésmentes állapot teherbírási vonala érinti a teherbírási vonalat (2. szakasz vége a 18. ábrán), akkor a repedésmentes állapotot jelzö külpontosságot a teherbírási vonal szabja meg. A 18. ábrán a 3. és a 4. szakaszok, a 19. ábrán pedig a szaggatott vonallal jelzett szakasz az, ahol a teherbírási vonalhoz tartozó külpontosság korlátozza a normálerő külpontosságát.

A magsáv mérete változó, és függ a normálerőtől, valamint az alakváltozásra fellágyuló ág hosszától $(k)$ és meredekségétől $(\gamma)$. Azt a normálerőt tekintjük a minimális magsáv határhoz $\left(k_{y \text { min }}\right)$ tartozónak, amelynél a külpontosság növelése során a teherbírási vonal eléréséig a keresztmetszet éppen repedésmentes, azaz ahol a repedésmentes teherbírási vonal érinti a teherbírási vonalat. (A 19. ábrán a szaggatott vonal szintje.)

A 20. ábra mutatja be azt, hogy az alakváltozásra fellágyuló anyagmodell paramétereinek változtatása hogyan változtatja a magsáv méretét. Látható, hogy az eltérő $\gamma$ értékekhez, a $k$ függvényében, hogyan változik annak a külpontosságnak az értéke, amelynél kisebb külpontosság esetén a keresztmetszet a teherbírási vonal eléréséig nem reped be, azaz mekkora a magsáv mérete. A $\gamma=$ állandó vonalakon feltüntetett fajlagos normálerőhöz tartozó szintvonalak azt mutatják, hogy annál nagyobb fajla-

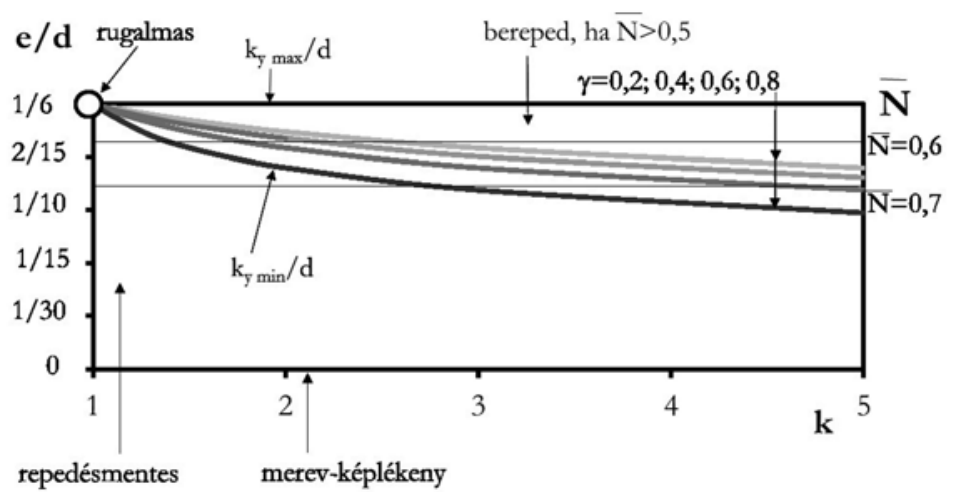

20. ábra. A magsáv méretének $\left(k_{y \text { min }}\right)$ változása a külpontosság és az alakváltozásra fellágyuló anyag törési összenyomódásának függvényében. A $\gamma=$ állandó vonalak a repedésmentes és berepedt állapot határai $\left(\gamma=0,2 ; 0,4 ; 0,6 ; 0,8 ; E_{o}=400 \mathrm{~N} / \mathrm{mm}^{2}\right)$ 
gos normálerő esetén a keresztmetszet nem reped be. A $\gamma=$ állandó vonalakhoz tartozó külpontosságig a keresztmetszet repedésmentes a teherbírás eléréséig. Ha $\bar{N} \leq 0,5$ és $e / d=1 / 6$, akkor a keresztmetszet mindig bereped. A $\gamma=$ állandó vonal és az $e / d=1 / 6$ közötti tartományban a normálerötől is függ, hogy a keresztmetszet a teherbírás elérése előtt bereped-e. Ebben a tartományban adott e/d értékhez tartozó $\bar{N}$ normálerőnél kisebb normálerőnél a keresztmetszet bereped a teherbírás elérése elött.

\subsection{A HELYETTESÍTŐ ANYAGMODELL}

A korábbi magyar szabvány a falazott szerkezetek méretezéséhez a lineárisan rugalmas-képlékeny anyagmodell alkalmazását írja elö. A jelenleg érvényes MSZ EN 1996-1-1:2009: Falazott szerkezetek tervezése című szabvány leírja, hogy nyomásra a falazat feszültség-alakváltozás diagramja nem lineáris-fellágyuló, de megengedi a keresztmetszetek méretezéséhez az azt helyettesítő diagram felvételét. A javasolt helyettesítő anyagmodellek függvényei lehetnek lineárisak, parabolikusak, parabola-téglalap vagy téglalap alakúak. Hasonló lehetőséget vet fel [4] is. A falazat viselkedését leíró feszültség-alakváltozás ábra viszont egy alakváltozásra fellágyuló, parabola diagramot ad meg, ami jól helyettesíthető az általunk vizsgált alakváltozásra lineárisan lágyuló anyagmodellel.

Készítettünk egy összehasonlító ábrát, ahol a különböző anyagmodellekhez megrajzoltuk a teherbírási vonalakat. A 21. ábrán a lineárisan rugalmas és a tökéletesen merev-képlékeny anyagmodell mellett megrajzoltunk egy korlátozott alakváltozási képességü képlékeny anyagmodellhez tartozó teherbírási vonalat is, ahol az alakváltozás határa megegyezett az alakváltozásra lágyuló anyagmodellével, azaz a törési összenyomódás értéke $\varepsilon_{u}$. Egy másik teherbírási vonalhoz úgy vettük fel a helyettesítö rugalmas képlékeny anyagmodellt, hogy a $\sigma-\varepsilon$ ábra alatti terület és a törési összenyomódás is megegyezzen az alakváltozásra lágyuló anyagmodellével. Vagyis a két anyagmodellhez azonos törési energia tartozzon.

A 21. ábrán jól látszik, hogy a merev-képlékeny anyagmodellek teherbírási vonalai felülről közelítik az alakváltozásra lágyuló anyagmodell teherbírási vonalát, azaz a biztonság kárára tévednek. A lineárisan rugalmas anyagmodell nagyon alulbecsüli a teherbírást, ugyan a biztonság javára téved, de így jóval nagyobb keresztmetszetek beépítését teszi szükségessé. Az a rugalmas-képlékeny anyagmodell, amely azonos területü és alakváltozási képességü az eredeti alakváltozásra lágyuló anyagmodellel, viszonylag jó egyezést eredményez, azonban nagy normálerő esetén ez az anyagmodell is alulbecsüli a keresztmetszet teherbírását, de a törési összenyomódáshoz tartozó minimális teherbírásnál mindig nagyobb teherbírást ad. Központos nyomás esetén azonban a különbség elérheti akár a $10 \%$-ot is.

Kis normálerőnél bármelyik anyagtörvényhez tartozó teherbírási vonal közel azonos értéket ad, de ez csak a normálerő tartomány 1/7-ére igaz. A maradék 6/7-ben 


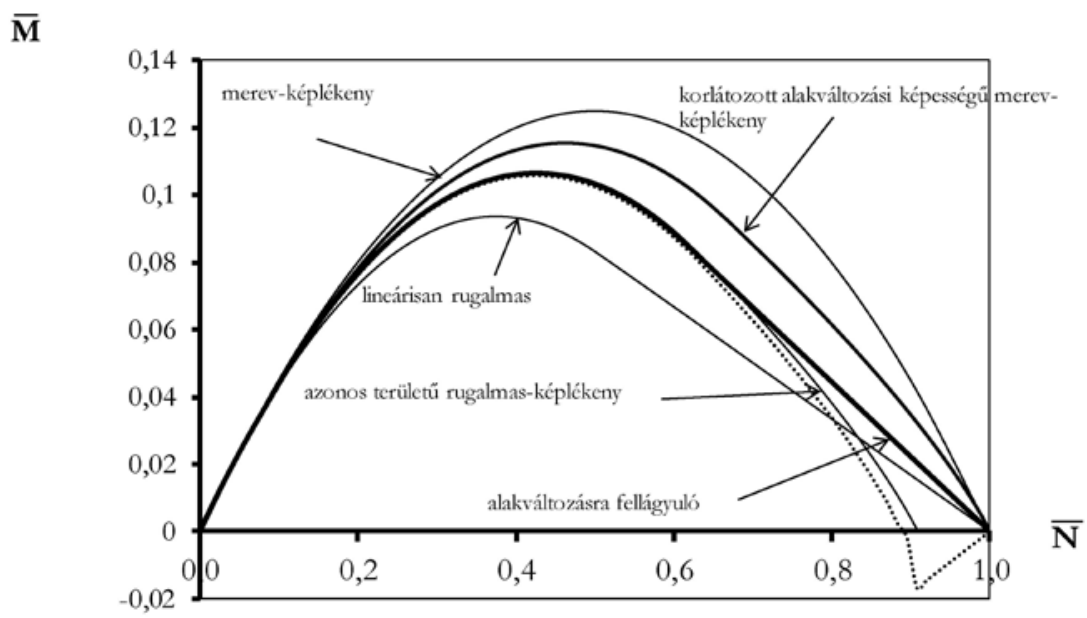

21. ábra. A különböző anyagmodellek összehasonlítása $(k=1,5, \gamma=0,8)$

jelentős eltérések lehetnek a keresztmetszet teherbírásában a különböző anyagmodellekkel számítva.

Mivel a különböző anyagmodellek szerinti teherbírási vonalak között nagy a különbség, ezért a „pontos” értékek kiszámításához az alakváltozásra lágyuló anyagmodellt célszerü alkalmazni, esetleg a területazonosság alapján meghatározott lineárisan rugalmas-tökéletesen képlékeny, korlátozott alakváltozású anyagmodellt.

\section{4. ÖSSZEFOGLALÁS}

A vályogfal teherbírásának vizsgálatához szükséges a keresztmetszet teherbírásának meghatározása. Ebben a tanulmányban bemutattuk a keresztmetszet teherbírási vonalának meghatározását az alakváltozásra lágyuló anyagmodell esetén. Vizsgáltuk az alakváltozásra lágyuló ág és a falazat keresztmetszetének teherbírási vonala közötti összefüggéseket, a fellágyuló ágat leíró paraméterek hatását $(k, \gamma)$, valamint azt, hogy az alakváltozásra lágyuló ág mely közbenső pontjához (mint korlátozott alakváltozáshoz) tartozik a falazat keresztmetszetének teherbírása. Azt az érdekes eredményt kaptuk, hogy egy határon túl már nem befolyásolja a teherbírást az alakváltozásra fellágyuló ág hossza. Azt az alakváltozást, ameddig még van eltérés a teherbírási vonalak között, az alakváltozásra fellágyuló ág hatékony hosszának nevezzük.

A teherbírási vonal mellett vizsgáltuk a keresztmetszet magsáv határát. Azt a normálerőt tekintettük a minimális magsáv határhoz tartozónak $\left(k_{y \text { min }}\right)$, amelynél a külpontosság növelése során a teherbírási vonal eléréséig a keresztmetszet éppen repedésmentes. Megállapítottuk, hogy a magsáv mérete változó, mérete függ a normál- 
erőtől, valamint az alakváltozásra fellágyuló ág hosszától $(k)$ és meredekségétől $(\gamma)$. A maximális magsávméret minden esetben a rugalmas anyaghoz tartozó $k_{y \max }=d / 6$.

Az alakváltozásra fellágyuló anyagmodellhez tartozó teherbírási vonal jelentősen eltér mind a lineárisan rugalmas, mind a tökéletesen képlékeny anyagmodellhez tartozó teherbírási vonaltól. Ezért azoknál az anyagoknál, ahol kísérlettel igazolható az alakváltozásra fellágyuló anyagmodell szerinti viselkedés, ott a pontosabb számítás érdekében nem közelíthető az anyagmodell sem a lineárisan rugalmas, sem a tökéletesen képlékeny anyagmodellel. Amennyiben az alakváltozásra fellágyuló anyagmodellt közelítjük más anyagmodellekkel, úgy a lineárisan rugalmas anyagmodell a biztonság javára, a tökéletesen képlékeny anyagmodell a biztonság kárára közelíti a keresztmetszet teherbírási vonalát. A biztonság javára közelítő, kielégítő pontosságú eredményt ad, ha lineárisan rugalmas-tökéletesen képlékeny, korlátozott alakváltozású anyagmodellt használunk. A modell paramétereit úgy kell megállapítani, hogy azonos legyen a két anyagtörvény törési összenyomódása és a görbék alatti terület.

\section{JELÖLÉSEK}

$\begin{array}{ll}a & \text { az alakváltozásra lágyuló ághoz tartozó feszültségi ábrarész mérete } \\ b & \text { a rugalmas állapothoz tartozó feszültségi ábrarész mérete } \\ d & \text { a keresztmetszet magassága } \\ h & \text { a keresztmetszet szélessége }(1,0 \text { méter) } \\ x & \text { a semleges tengely helye a nyomott szélső száltól } \\ k & \begin{array}{l}\text { a fellágyuló anyagtörvény jellemzö fajlagos összenyomódásainak } \\ \text { aránya }\end{array} \\ k_{y} & \text { a magsáv mérete } \\ N & \text { a keresztmetszeten müködő normál erő } \\ M & \text { a keresztmetszeten müködő hajlítónyomaték } \\ \bar{N}=N / h d \sigma_{0} & \text { fajlagos normál erő } \\ \bar{M}=M / h d^{2} \sigma_{0} & \text { fajlagos hajlítónyomaték } \\ \varepsilon_{o} & \text { a maximális feszültséghez tartozó fajlagos összenyomódás } \\ \varepsilon_{u} & \text { a maximális fajlagos, törési összenyomódás } \\ \sigma_{o} & \text { a maximális feszültség nagysága } \\ \sigma_{u} & \text { a maximális fajlagos összenyomódáshoz tartozó feszültség nagysága } \\ \gamma & \text { a fellágyuló anyagtörvény jellemzö feszültségeinek aránya } \\ \kappa & \text { a keresztmetszethez tartozó görbület }\end{array}$




\section{IRODALOM}

[1] Árva P. - Sajtos I.: Kitöltött és kitöltetlen állóhézagú falazat alakváltozási jellemzőinek meghatározása. Épités - Épitészettudomány 40 (2012) 3-4. 211-240.

[2] Bažant, Z. P.: Is no-tension design of concrete or rock structures always safe? - Fracture analysis. Journal of Structural Engineering 122 (1996) 1. 2-10.

[3] Bažant, Z. P. - Cedolin, L.: Stability of structures. Elastic, inelastic, fracture and damage theories. Oxford University Press, New York 1991.

[4] Chen, Y. - Ashour, A. F. - Garrity, S. W.: Moment/thrust interaction diagrams for reinforced masonry sections. Construction and Building Materials 22 (2008) 763-770.

[5] Csicsely Á. - Józsa Zs. - Sajtos I.: Vályogfalazat nyomószilárdsági vizsgálata. Építöanyag 56 (2004) 4. 159-163.

[6] O. Csicsely Á.: Vályogfalak kisérleti és elméleti teherbírásvizsgálata. PhD értekezés, BME Építészmérnöki Kar, Budapest 2006.

[7] De Falco, A. - Lucchesi, M.: Stability of columns with no tension strength and bounded compressive strength and deformability. Part I: large eccentricity. International Journal of Solids and Structures 39 (2002) 6191-6210.

[8] Macskási R. - Domokos G. - Sajtos I.: Producing interaction curves by geometric transformation. Proc. of the $3^{\text {rd }}$ Int. PhD Symposium in Civil Engineering. Vienna, Ausztria, 2000. 10. 05.-2000. 10. 07. 479-488.

[9] Jäger, W. - Graubner, C. A.: Knicksicherheit von Mauerwerk, Beitrag im Mauerwerk-Kalender 2002. Ernst \& Sohn GmbH, Berlin 2002.

[10] Kaliszky S. - Kurutzné Kovács M. - Szilágyi Gy.: Mechanika II. Szilárdságtan. Tankönyvkiadó, Budapest 1990.

[11] Kollár L.: Vasbeton szilárdságtan. Mủegyetem Kiadó, Budapest 1995.

[12] MSZ EN 1052-1:2000 Falazatok vizsgálati módszerei. 1. rész: A nyomószilárdság meghatározása.

[13] Palmer, A. C. - Maier, G. - Drucker, D. C.: Normality relations and convexity of yield surfaces for unstable materials and structural elements. Journal of Applied Mechanics (1967) 464-470.

[14] Sajtos, I.: Falazott szerkezetek anyagai. Szerk.: Fernezelyi S. - Matuscsák T.: Épületek teherhordó szerkezetei. Aktuális szerkezeti megoldások tervezöknek, kivitelezöknek. 6.4. fejezet. Verlag Dashöfer Szakkiadó Kft. és T. Bt., Budapest 2004.

[15] Sipos A. Á.: Személyes közlés. 2005.

[16] Szücs M.: Föld- és vályogfalú házak épitése és felújitása. Építésügyi Tájékoztatási Központ Kft., Budapest 2002.

[17] Zucchini, A. - Lourenco, P. B.: A micro-mechanical model for the homogenisation of masonry. International Journal of Solids and Structures 39 (2002) 3233-3255. 


\title{
LOAD-BEARING CAPACITY OF THE STRAIN SOFTENING, NO-TENSION - ADOBE - MASONRY ELEMENT
}

\begin{abstract}
Summary
Load-bearing capacity of the masonry element subjected to eccentric compression was determined. No-tension, strain softening material model was used corresponding to the experiments. The family of the engineering material models can be determined by the suggested one varying the parameters of the model. Load-bearing capacity of the masonry element cannot be determined by chosing stipulated failure states. It is given by the maximum of the moment-curvature function. It was found that failure states are not necessarily forecasted by cracks. It was also found that the behaviour of the masonry element is also changed from ductile to brittle by changing the internal forces. The core-strip of the wall cross-section, which is the area of the eccentric forces not causing cracks, is dependent on the parameters of the material law and the acting compression force too. A simplified but accurate enough material law was suggested to substitute the no-tension, strain softening material law.
\end{abstract}

Keywords: adobe, masonry element, strain softening material, interaction curve 